\title{
Probleme Dayalı Öğrenme Süreci: Mevcut Durum, Sorunlar ve Teknoloji Destekli Çözüm Önerileri *
}

\section{Problem Based Learning: Present Situation, Issues and Technology Supported Solution Recommendations}

\section{I.İ̀rem BUDAKOĞLU**}

Received: 20 February 2018

\author{
Özlem CoşKUN ${ }^{* * *}$
}

\section{Vildan ÖZEKE ${ }^{* * * * * *}$}

\begin{abstract}
In this study, we tried to discuss the problematic issues in the problem based learning (PBL) process as a frequently used method in medical faculties. The issues were based on experiences while applying PBL and their existence in the literature. After determining the issues, we have presented technology supported solution recommendations with the help of the literature. This is a qualitative study based on interview records with eight PBL facilitators and two planning staff. The problematic issues in present situation about PBL process are as follows; physical space and facilitator organization, printed scenarios, the problems while evaluating student performance, simultaneous and out-of-class workload of PBL facilitators, and Generation $\mathrm{Z}$ learners and their access to the sources and library. We tried to get solutions to these issues from the literature by using the support of e-learning technology. Presenting learning environments that will enable current medical students -who are the $21^{\text {st }}$ century learners- to gain technical and life skills will enhance their clinical thinking/reasoning, problem solving and communication skills professionally and technically.
\end{abstract}

Keywords: problem based learning, medical education, technology use in education, e-PBL, digital scenario.

ÖZ: Bu çalışmada tıp fakültelerinde sıklıkla kullanılan bir yöntem olarak probleme dayalı öğrenme (PDÖ) sürecinde gözlenen ve literatürde de değinilen bir takım sorunlar ele alınmış ve bu sorunlara teknoloji destekli çözüm önerileri sunulmuştur. $\mathrm{Bu}$ çalışma nitel araştırma yöntemiyle planlanmıştır. Sekiz öğretim üyesi ve PDÖ oturumlarını planlamadan sorumlu iki idari personelle yürütülen bireysel görüşmeler ile mevcut durum ortaya konulmuştur. PDÖ’ye ilişkin mevcut sorunlar; fiziksel mekân ve yönlendirici organizasyonu, kâğıt-kalem temelli senaryo sunumu, öğrenci performansının değerlendirilmesine ilişkin sıkıntılar, PDÖ yönlendiricilerinin eş zamanlı ve ders dışı iş yükü ile z kuşağ1 öğrenenleri ve bu öğrencilerin kaynak ve kütüphaneye erişimleri alt başlıkları altında ele alınmıştır. Alanyazından elde edilen veriler ışığında PDÖ sürecinde yaşanan bu sorunlara teknoloji destekli olarak ne tür çözüm önerileri getirilebileceği ele alınmaya çalışılmıştır. 21. yüzyıl öğrenenleri olarak hâlihazırdaki tıp fakültesi öğrencilerine teknik ve günlük yaşam becerilerini kazanacakları öğrenme ortamları sunmak, özellikle klinik düşünme/akıl yürütme, problem çözme ve iletişim becerilerini arttırırken, mesleki ve teknik anlamda da gelişimlerini sağlayacaktır.

Anahtar kelimeler: probleme dayalı öğrenme, tıp eğitimi, eğitimde teknoloji kullanımı, e-PDÖ, dijital senaryo.

\footnotetext{
${ }^{*}$ This study is supported by TUBITAK as part of 117 S006-numbered project.

${ }^{* *}$ Corresponding Author: Prof. Dr., Gazi University, Ankara, Türkiye, isiliremb@ gmail.com

*** Instructor Dr., Gazi University, Ankara, Türkiye, drozlemcoskun@gmail.com

**** Asst. Prof. Dr., Gaziosmanpaşa University, Tokat, Türkiye, vildancevik@gmail.com
}

\section{Citation Information}

Budakoglu, İ., Coskun, Ö., \& Özeke, V. (201?). Probleme dayalı öğrenme süreci: mevcut durum, sorunlar ve teknoloji destekli çözüm önerileri. Kuramsal Eğitimbilim Dergisi [Journal of Theoretical Educational Science], 11(4), 894-921. 


\section{Giriş}

Öğrencinin “aktif öğrenenler” olarak merkezde olduğu (Şendağ \& Odabaşı, 2009) bir yöntem olarak probleme dayalı öğrenme (PDÖ) tıp eğitiminde teorik bilgi ile uygulama pratiği arasındaki boşluğu doldurmada köprü görevi yapan (Demirören \& Demirel, 2006; Gould, Sadera \& McNary, 2015) önemli bir role sahiptir. PDÖ yöntemi 1960'ların sonunda McMaster Üniversitesinde başlayıp (Zubaidah, 2005; Maldonado, 2011), 1970'lerden beri tıp eğitiminde klinik problemlerin sunumunda kullanılmaktadır (Gould vd., 2015). Türkiye'de ise 1997-1998 akademik yılında ilk defa Dokuz Eylül Üniversitesi Tıp Fakültesi'nde üçüncü sınıfa kadar olan süreçte PDÖ merkezli bir program başlatılmıştır (Musal, Keskin \& Tuncel, 2016).

PDÖ yöntemi, vakadan hareketle bilimsel akıl yürütme becerilerini kullanmak suretiyle kanıta dayalı tıp felsefesinin, öğrenim hedeflerini belirleme ve araştırma görevlerinin öğrencide oluşuyla kendi kendine öğrenme becerisinin, grup içinde liderlik ve grup ortamında uygun davranış ve ifade becerilerinin geliştirilmesine olanak tanıyan bir öğrenme yöntemidir (Yıldız-İnanıc1, 2014). Çünkü bu süreçte öğrenciler bir senaryo temelinde saptanan sağlık sorunlarını çözerken, önceki bilgilerini kullanmakta, ihtiyaç duydukları yeni öğrenmeleri belirlemekte, yeni bilgileri tartışarak işlemekte ve aktif oldukları bu süreçte pek çok bilişsel kazanım elde etmektedirler (Musal vd., 2016). Öğrencilerde merak uyandırması, temel tıp ile klinik branşları birbirine bağlayan senaryolar üzerinden kendilerinde eksik olan bilgileri belirleyerek araştırmaya çalışmaları PDÖ yönteminin güçlü yönleri olarak ele alınabilir.

PDÖ yönteminin özellikle tıp alanında zengin ve güçlü olduğu meta-analiz çalışmalarında da görülmüştür (Strobel \& van Barneveld, 2009). Böylelikle eğitimin erken dönemlerinde klinik ve teoriyi birleştirerek tıp öğrencilerini klinik karar verme ve akıl yürütmeye yönlendirmekte, onların mesleğe uyum süreçlerini hızlandırmaktadır (Demirören \& Demirel, 2006). Bu yöntemde öğrenciler tam belirli olmayan bir problem durumu üzerinden senaryodaki vakaya ilişkin problemi anlamaya, probleme ilişkin olası hipotezler kurmaya, bilgi eksiklikleri olan konuları belirleme ve araştırmaya, çözüm yolları önermeye, edindikleri bilgi ve tecrübelere dayanarak olası çözümleri değerlendirmeye çalışırken (Persson, Fyrenius \& Bergdahl, 2010; Gürpınar, Tetik, Alimoğlu \& Akdoğan, 2011) hem kendi öğrenmelerini yönetirler hem de problem çözme becerilerini geliştirirler (Demirören \& Demirel, 2006; Vosinakis, Koutsabasis, Zaharias \& Belk, 2012, Musal vd., 2016). Bu süreçte öğrenciler belki hiçbir önbilgilerinin dahi olmadığı durumlarda (Vosinakis vd., 2012) bilgiyi derin biçimde anlama ve uzun süreli hatırlama konusunda kazanımlar elde etmekte (Valaitis, Sword, Jones, \& Hodges , 2005; Spinello \& Fischbach, 2008; Strobel \& van Barneveld, 2009) ve grup işbirliği, eleştirel düşünme (Vosinakis vd., 2012; Gavgani, Hazrati \& Ghojazadeh, 2015) ve iletişim becerileri (Demirören \& Demirel, 2006; Gürpınar vd., 2011; Musal vd., 2016) kazanmaktadırlar. Bu yöntemin klinik akıl yürütme becerilerini de geliştirdiği belirtilmektedir (Rounds \& Rapport, 2008). PDÖ yönteminin öğrenme ve başarı üzerinde güçlü bir etkisi olduğu söylenmektedir (Schmidt, Rotgans \& Yew, 2011). Öğrenenlerin özyeterlik algısının ve transfer becerilerinin çevrimiçi ortamda yapılan PDÖ ile yükseldiği söylenmektedir (Onan, 2011). Grup işbirliği ve etkileşimini, özellikle küçük gruplarda öğrenmeyi daha ilginç ve çekici k1lan PDÖ yöntemi, öğrenenin akranlarıyla bilgi alışverişini desteklemektedir (Spinello \& Fischbach, 2008). 
İletişim ve etkileşim bu yöntemin gerek yüz yüze gerekse çevrimiçi ortamda yapılmasında en kritik iki öğedir (Akt. Vosinakis vd., 2012). Öğrenenler birbirleriyle ne kadar çok etkileşime girer ve tartışırlarsa senaryoyu o kadar çok sevmekte, problem ne kadar gerçekçi ve aslına uygun ise de o kadar probleme dahil olabilmektedirler (Persson vd., 2010). Diğer taraftan kullanılan senaryoların sadece biyolojik hedeflere değil, toplumsal ve davranışsal hedeflere de ulaşılacak biçimde kurgulanması (Musal, Akalın, Kılıç, Esen \& Alıc1, 2002), öğrenenlerin çevresel ve sosyal faktörlere de yoğunlaşarak, çok yönlü bakış açısı ve yorumlama becerileri elde etmelerini sağlayabilir. Öğrencilerin öğrenme ihtiyacı hissettikleri konuları kendilerinin belirleyerek öğrenme hedefleri çıkarmaları içsel motivasyonlarını arttırmaktadır (Musal vd., 2002).

2010 Türk Tabipler Birliği Mezuniyet Öncesi Tıp Eğitimi Raporu’na göre 56 tıp fakültesinden 34'ünde $(\% 60,7)$ karma, 18 'inde $(\% 32,1)$ eğitici merkezli ve 4'ünde $(\% 7,1)$ öğrenci merkezli eğitim modeli kullanılmaktadır (MOTE, 2010). Karma ve öğrenci merkezli eğitim uygulayanların 30'unda, PDÖ, toplam müfredatın \%10'undan azını kapsarken, 8'inde ise \%10-25'ini kapsamaktadır (MOTE, 2010). Karma eğitim uygulanan Tıp Fakültelerinde PDÖ ilk üç yılda yapılmaktadır. Mezuniyet Öncesi Tıp Eğitimi Ulusal Standartları (UTEAK, 2014) incelendiğinde, öğrencilerin mezuniyet aşamasında sahip olmaları gereken yeterliklerin kapsaması gereken alanlarda "genel hekimlik becerileri” başlığı altında; analitik, eleştirel düşünme, klinik sorgulama-akı1 yürütme, problem çözme, bilgiye ulaşma ve kullanma, yaşam boyu öğrenme, iletişim, ekip çalışması vb. beceriler yer almaktadır. TS.2.7.2. nolu standartta ise 2015 yılından itibaren öğrencilere ekip çalışması anlayışı ve becerilerini kazanmalarına yönelik firsatlar sağlanması gerektiği belirtilmekte ilgili etkinlikler arasında probleme dayalı öğrenme de yer almaktadır.

Her PDÖ, üç oturum şeklinde yapılandırılmıştır. Birinci oturumda senaryonun kapak sayfası dağıtılır ve tartışılır. Ardından ilk sayfa dağıtılarak senaryo bölümü ve soruları okunur, tartışılır ve tabloya işlenir. Senaryoyu izleyen sayfalar da okunarak aynı şekilde tablodaki uygun alanlara bilgiler işlenir. Senaryonun özeti yapılır ve hangi noktaya ulaşıldığı belirlenir. Ardından sürece ilişkin geribildirimler verilir-alınır. İkinci ve üçüncü oturumlarda ise, önceki oturum gözden geçirilir, önceki oturumda belirlenen öğrenim hedefleri öğrenciler tarafından aktarılarak tartışılır. Öğrenilen bilgiler çerçevesinde önceki oturumda ortaya konulan hipotezler gözden geçirilir. Senaryo ile ilgili yeni sayfalar dağıtılarak okunur, tartışılır ve tabloya işlenir. Senaryo özetlenerek ulaşılan nokta belirlenir. Sürece ilişkin geri bildirim alıp verme ile bir sonraki basamağa geçilir veya tamamlanır. PDÖ yönteminde izlenen yol öğrencileri küçük gruplara bölerek bir senaryoya ilişkin planlanan üç farklı oturumun her birinde farklı görevleri gerçekleştirmelerini beklemektir. Oturumlar genellikle yüz yüze yapılmakta ve bir PDÖ yönlendiricisi (öğretim üyeleri) katılımlı olarak yürütülmektedir. Öğrenciler arasında; yazıc1, okuyucu, kitaplardan kaynak arayanlar ve internetten kaynak arayanlar şeklinde çeşitli görev dağılımları yapılmaktadır. Okuyucu senaryoyu sesli okurken, yazıcı küçük tahtayı herkesin görebileceği şekilde dörde böler ve her bir bölmeye bulgular, hipotezler, ek bilgiler ve ögrenim hedefleri başlıklarını yazar. Senaryo ilerledikçe tartışmalarla birlikte bu başlıkların altını hep birlikte tamamlarlar (Bkz. Resim 1). 
Resim 1. PDÖ Senaryosu Oturum Sonu Özeti

Resim 2. Probleme Dayalı Öğrenme Dersliği
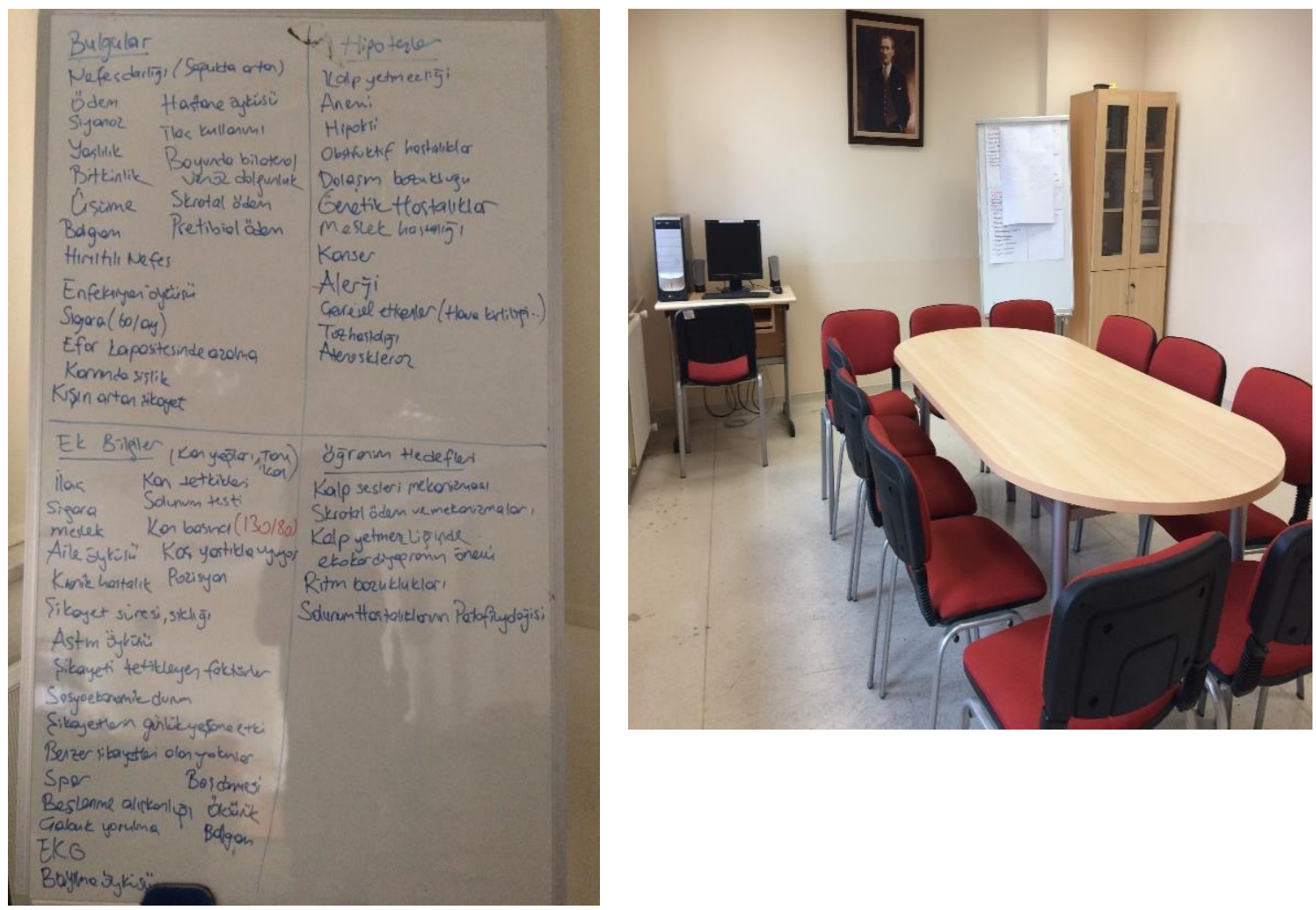

Fakülte bünyesinde toplam 20 tane küçük sınıf bulunmaktadır. Bu küçük sınıflarda PDÖ uygulamalarının yanı sıra, iletişim becerileri, akılcı ilaç kullanımı ve klinik beceri gibi küçük grup uygulamaları yürütülmektedir. Aşağıdaki fotoğrafta (Resim 2) fakültenin PDÖ dersliklerinden birinin görüntüsü sunulmuştur.

Fotoğrafta da görüldüğü üzere 20 küçük derslikten 12 tanesi bu şekilde iken, 8 tanesinde kütüphane bulunmamaktadır. Kütüphanenin olmadığı derslikler klinik beceri uygulamaları için kullanıldığından, onlarda da farklı olarak el yıkama lavabosu mevcuttur.

PDÖ yönteminin etkililiği ve önemi yukarıda da belirtildiği üzere tartışma götürmemektedir. Yapılacak çalışmalar ideal PDÖ ortamında iletişim biçimleri, yönlendiricinin rolü ve nasıl destek olması gerektiği konularında yürütülebileceği gibi, PDÖ yönteminin başarılı olması için farklı ne tür stratejilerin işe koşulabileceği üzerine de planlanmalıdır (Strobel \& van Barneveld, 2009). Bu çalışmada amaç, PDÖ sürecinde mevcut durumu ve yaşanan sıkıntıları ortaya koymak, bu sıkıntılara teknoloji destekli çözüm önerileri sunmaktır. Bu çerçevede çalışmanın birincil alt amacı; yüz yüze PDÖ dersliklerinde yürütülen oturumlarda yaşanan mevcut sorunları belirlemektir. İkincil alt amaç ise; belirlenen sorunlara teknoloji destekli çözüm önerilerini katılımcı görüşleri ve literatür desteğiyle ortaya koymaktır.

\section{Yöntem}

$\mathrm{Bu}$ çalışma nitel araştırma yöntemiyle planlanmış olup, Datta (1990)'ın "Program Yürütme Durum Çalışması” (Akt. Davey, 1991) türünde yapılandırılmıştır. 
Program yürütme durum çalışmaları, uygulamanın amacına uygun biçimde yürüyüp yürümediğini, uygulamada varsa problemlerin belirlenmesini sağlaması bakımından tercih edilmektedir (Akt. Davey, 1991). Çalışmada yarı yapılandırılmış görüşme ile veri toplanmıştır (Yıldırım \& Şimşek, 2005). Görüşme; genellikle yüz yüze ve sözlü iletişim yöntemiyle yürütülen bir veri toplama yöntemidir (Karasar, 2004). Bireylerin bakış açılarını anlamanın bir yolu olarak görüşme yöntemiyle, deneyimler, tutumlar, düşünceler, niyetler, yorumlar ve zihinsel algılar ve tepkiler gibi gözlenmesi imkansız süreçler anlaşılmaya çalışılır (Yıldırım \& Şimşek, 2005). Görüşmelerin en güçlü özelliği, göremediklerimiz hakkında bilgi edinme ve gördüklerimiz hakkında ise detaylı açıklamalar yapma firsatı vermesidir (Glesne, 2015).

\section{Çalışma Grubu}

Gazi Üniversitesi Tıp Fakültesi öğretim üyesi ve idari personelden oluşan katılımcılar bu araştırmanın çalışma grubunu oluşturmaktadır. Çalışma grubu belirlenirken, öğretim üyelerinde PDÖ yönlendiriciliği eğitimi almış, çok kez PDÖ oturumunu yönetmiş olma ve çalışmaya katılıma gönüllü olma kriterleri aranmıştır. Görüşülen öğretim üyelerinden beşi, PDÖ Kurulu'nda yıllarca görev almış veya kurul başkanlığı yapmış, PDÖ senaryoları yazım ekibinde bulunmuş ve en az 30 defa PDÖ yürütmüştür. Ayrıca dahili, cerrahi ve temel tıp bilimleri gibi farklı bölümlerin bakış açılarını sunmak adına her bölümden öğretim üyesine ulaşılmaya çalışılmıştır. Üçü erkek ve beşi kadın olmak üzere toplamda sekiz öğretim üyesiyle bireysel görüşme yapılmıştır. Öğretim üyelerinin yedisi profesör ve biri doçent olup, temel bilimlerde dört, dâhili bilimlerde üç ve cerrahi bilimlerde de bir kişi görev yapmaktadır. Görüşme yapılan idari personel ise, PDÖ planlanmasında biri dokuz diğeri 15 y1ldır görev yapıyor olup, bir kadın ve bir erkek olmak üzere iki kişidir. İdari personel, sürecin fiziksel ortam ve koşullarını düzenliyor olmaları bakımından sürece ilişkin sorunlara hâkim oldukları ön düşüncesiyle, çalışmaya dâhil edilmiştir.

\section{Veri Toplama Süreci}

Tüm katılımcılar gönüllü olup, görüşme esnasında ses kayıtlarının alınmasını onaylamışlardır. Yürütülen görüşmelerde, öğretim üyesi ve idari personel için ayrı ayrı hazırlanan yarı-yapılandırılmış görüşme formları kullanılmıştır. Öğretim üyelerine;

- PDÖ oturumunun planlanmasında,

- PDÖ oturumunu sınıf içinde yürütürken yaşadıkları sorunlar

- Sınıf dışında yürütürken yaşadıkları sorunlar

- PDÖ’nün yüz yüze değil de çevrimiçi olarak yürütülmesi hakkında ne düşündükleri sorulmuştur.

İdari personele ise;

- PDÖ sürecinde ne tür görevler aldıkları,

- Bu sürecin öncesinde, esnasında ve sonrasında ne tür sıkıntılar yaşadıkları,

- Bu sürecin daha etkili yürütülmesi için görüş ve önerileri sorulmuştur.

Öğretim üyeleri ve idari personel ile yapılan görüşmeler bir araştırmacı tarafından yürütülmüştür. Öğretim üyelerinden birinin görüşmesinde ses kayıt esnasında oluşan bir teknik sorun nedeniyle görüşmenin belli bir aşaması kayıt edilememiştir. 
Yarım saat kadar süren görüşmede sadece 5:45 dakikalık görüşme ses kayıt cihazında tutulabilmiştir. $\mathrm{Bu}$ aşamada görüşmeci, konuşmanın ses kayıt cihazında mevcut kısmının transkriptinden sonra, dinlerken aldığı notlarını da metne eklemiş, ilgili öğretim üyesine e-posta ile göndermiş ve öğretim üyesinden ifadelerini onaylamasını talep etmiştir. Öğretim üyesi ilgili belgeyi yaptığı bazı değişikliklerle teyit etmiş ve araştırmacıya e-posta ile geri göndermiştir. Veri analizinde bu son belge kullanılmıştır.

\section{Verilerin Analizi}

Görüşmeler transkript edildikten sonra ise, öğretim üyelerinden 13.831 kelime (ortalama: 1728) ve idari personelden de 926 kelimeden (ortalama: 463) oluşan metinler elde edilmiştir. Yapılan görüşmelerin mevcut ses kayıtları yukarıda bahsedilen teknik sıkıntı nedeniyle en az 5:45 dk/sn en çok 32:40 dk/sn olup; ortalaması öğretim üyeleri için 15,5 dakika, idari personel için 9,4 dakikadır. Elde edilen tüm metin içerik analizi yöntemi ile tema ve alt temalara ayrılmıştır. Metinlerin analizinde araştırmacılar eşzamanlı olarak bir arada çalışmıştır. Katılımcıların belirttiği sorunlara ve çözüm önerilerine ilişkin ortaya çıkan görüşler alıntılar şeklinde verilmiştir. Öğretim üyelerinden yapılan alıntılar için ÖÜ kısaltması, PDÖ sürecini planlamakla görevli idari personelden yapılan alıntılar için de İP kısaltması kullanılarak, her ifadenin kim tarafından ortaya konulduğu numaralı ve cinsiyet bilgisini de içerecek biçimde (K: Kadın, E: Erkek) sunulmuştur.

\section{Geçerlik ve Güvenirlik}

Çalışmanın güvenirliği için görüşmelerin ses kayıtlarından elde edilen transkriptler bir kişi tarafından yazıya döküldükten sonra bir başka kişi tarafından tekrar dinlenerek, eksik veya atlanan ifadeler düzeltilmiştir. Tüm araştırmacılar kendi bireysel kodlamalarını yaptıktan sonra, temaların isimlendirilmesi sürecinde eşzamanlı olarak beraber çalışmışlardır. Çalışmanın iç geçerliği için, öğretim üyelerine ek olarak PDÖ planlamasından sorumlu idari personel ile de görüşülerek veri kaynağı çeşitlemesi yapılmıştır. Elde edilen bulguların katılımcılarla teyit edilmesi de iç geçerlik için bir başka yöntemdir. Bulguların literatürle uyumlu olması çalışmanın dış geçerliğinin kanıtı olarak ele alınabilir.

\section{Bulgular}

Öncelikle mevcut duruma ilişkin sorunlar beş tema altında toplanmıştır. Görüşmeler, literatürden elde edilen veriler ışığında ele alınmış, bu sorunlar alt başlıklar halinde listelenmiştir. Ardından bu sorunlara kuramsal alanyazından elde edilen teknoloji destekli çözüm önerileri sunulmuştur.

\section{Probleme Dayalı Öğrenme Süreci ve Sürece İlişsin Mevcut Sorunlar}

Fiziksel mekân ve yönlendirici organizasyonu. PDÖ yönteminde küçük grup oluştururken çok sayıda paralel oturum planlanmaktadır. Daha önceki yıllarda PDÖ grupları 7-8 öğrenciden oluşurken, şu an 10'ar kişilik gruplarla yürütülmektedir. Fiziksel mekan ve yönlendirici organizasyonu sorununa ilişkin temalar Tablo 1'de sunulmuştur. 
Tablo 1

Fiziksel Mekan ve Yönlendirici Organizasyonu Sorununa İlişkin Temalar

\begin{tabular}{ll}
\hline Temalar & Alt temalar \\
\hline Fiziksel mekân & \\
\hline Gruplardaki kişi sayısının artması & $\begin{array}{l}\text { Sınıfa sığmanın zorlaşması } \\
\text { Dışarıdan sandalye takviyesi gerekmesi } \\
\text { Sinıflar küçük, ortamın havasız olması } \\
\end{array}$ \\
& Öğretim üyesi ve öğrencinin rahatsızlık hissetmesi \\
\hline Yönlendirici organizasyonu & Öğretim üyesinin gelemeyeceğini son dakika bildirmesi \\
\hline İptal talepleri & Son dakika değişikliğe bağlı öğretim üyesi bulmanın imkânsız oluşu \\
& Gelmeyen öğretim üyelerinin gruplarının diğer gruplara dağıtılması
\end{tabular}

Aşağıda katılımcıların fiziksel mekan ve yönlendirici organizasyonuna ilişkin görüşlerinden birkaç örnek verilmiştir:

ÖU4, K: Sayı artıyor. Mesela ilk zamanlar 7-8 kişi gibi çok iyiydi. Sonra bir 10-11 oldu. En son 14 ile yaptım ben. Sanırım 17 ile yapanlar da olmuş. Bana 17'lik grup gelmedi. Sandalyeyi yan odalardan veya desklerden alıyoruz. Yani grup şey, tam sığmıyor yani öğrenciler o ortama. Öyle gruplar oluyordu.

ÖU2, E: Tabiki grubun belli bir sayının üstüne çıkmaması gerekiyor. Sınıfın metrekaresi, ortamın diyelim ki oksijen oranı bile çok önemli. Çok önemli parametreler bunlar. Kendini rahat hissetmesi, hava alması, relaks (relax) davranması açısından. Sınıfların metrekare olarak hesaplanıp, diyelim ki 10 kişi ise, 10 kişinin üstüne çıkılmamalı. Çıkıldığı anda bu işin ambiyansı bozulabiliyor. Çünkü bu sefer hem sizin de odağınızı dağıtabiliyorlar, kendileri de kendi aralarında farklı bir konekşına (connection) girebiliyorlar. Onun için bu yönüyle sıkıntılı olabilir.

İP2, E: Bazen PDÖ günü geliyor, bazı yönlendiriciler ben katılamayacağım diyor. Günü gelmeden haber verirlerse daha iyi olur. Son anda olunca biz zor durumda kalıyoruz. Başka hocaya ulaşsak bile gelmiyorlar. Biz de tekrar grupları ayarlıyoruz, bir grupta 10 kişi olması gerekirken bu sefer de 12-13 kişi oluyor sınıflarda. Sorun yaşıyoruz yer konusunda. Sınıflarımız küçük kalıyor grup sayısına göre.

Kağıt-kalem temelli senaryo sunumu. Yüz yüze olarak yürütülen PDÖ oturumlarında, senaryo ve kaynakların verilmesinde, oturumlar esnasında not alırken, senaryo özeti tahtaya işlenirken ve değerlendirme yapılırken kâğıt-kalem kullanılmaktadır. Basılı formda verilen senaryolarda bir okuyucu seçilerek sayfa sayfa ilerlenmekte, yazıcı özet biçimde tahtaya verileri işlemekte ve senaryoya ilişkin ek veriler (röntgen, tahlil veya tetkik sonuçları, EKG, solunum testi sonuçları... vb.) fotokopi şeklinde çoğaltılmaktadır. Gerek görüntü kalitesinin bozulması gerekse renkli bask1 olmaması nedeniyle, radyolojik görüntülerin kalitesinde bozulma veya patoloji preparatlarındaki boyamanın görünmeyişi gibi durumlar ortaya çıkmaktadır. Görsellerde yüksek çözünürlük elde edilememektedir, ayrıca kâğıt tüketimi de artmaktadır. Senaryoların kağıt-kalem temelli sunulmasına ilişkin temalar Tablo 2'de sunulmuştur. 
Tablo 2

Senaryoların Kağıt-Kalem Temelli Sunulması Sorununa İlişkin Temalar

\begin{tabular}{ll}
\hline Tema & Alt temalar \\
\hline \multirow{2}{*}{ Kâğıt-kalem temelli senaryo sunumu } & Baskı kalitesinden dolayı görüntülerin net olmayışı \\
& Renkli olmayıp siyah beyaz oluşu \\
& Aşırı kâğıt tüketimi \\
& PDÖ kurulunun senaryoları fotokopide çoğaltılması için geç \\
& ulaştırması, fotokopi için zamanın sıkışması
\end{tabular}

Aşağıda katılımcıların senaryoların kağıt-kalem temelli sunulmasına ilişkin görüşlerinden birkaç örnek verilmiştir:

ÖU4, K: Kötü oluyor. Fotokopi olmamalı. Biz ekrana yansıtmayı tercih etmiştik, bir sickle cell anemi, orak hücreli aneminin periferik yayma bulgularını patoloji hocasıyla birlikte koymuştuk. O zaten basmayalım demişti. Direkt ekrana koyduk. Zaten de hani internete da yazsanız da çoğu yerden çıkıyor. Hani orak hücreli anemide nasıl sickling oluyor diye. Hani ben ekranı mesela tomografi, MR, büyüme eğrileri, ekrana koymayı daha çok uygun buluyordum. ... Ama bazı şeyler dediğiniz gibi fotokopide kayboluyor. Fotokopi yapmak doğru değil.

ÖU6, K: Röntgen filmleri falan gayet güzel; bilgisayarda olunca güzel oldu. Eskiden basıl1 geliyordu. Onu bazen anlayamıyorduk, iyi basılamıyor. Fotokopiler iyi olmuyordu ama ekranda olunca filmler gayet güzel görünüyor.

ÖU7, K: Senaryonun fotokopi şeklinde sunulmasının zorlukları olduğunu biliyorum. Aslında hani şu olabilir belki odalardaki bilgisayarlara yüklenebilir. Bu yazılı materyal olması yerine. Öğrenciler zaten hepsi orada oluyorlar. Sorular oradan, senaryo oradan izlenebilir. Hani o açıdan bir kolaylık olabilir. Kâğıt tüketimi azalabilir bu sayede. Hani illa ki basılması gerekmiyor. Senaryo akışı bilgisayar ekranından da izlenebilir.

Öğrenci performansının değerlendirilmesi. Gruplardaki bireylerin probleme dayalı öğrenme becerilerinin belirlenmesinde, PDÖ yönlendiricisi tarafından bireysel gözleme dayalı olarak değerlendirme yapılmaktadır. Öğretim üyeleri değerlendirmeyi basılı formlara işlemektedir. Kendi değerlendirmelerine ek olarak, öğrencilerin de oturumu ve senaryoyu değerlendirdikleri formlar bulunmaktadır. Tüm bu formlar öğretim üyesi tarafından üçüncü oturumun sonunda planlamadan sorumlu idari personele iletilmektedir. Öğrenci performansının değerlendirilmesi sorununa ilişkin temalar Tablo 3'de verilmiştir. 
Tablo 3

Öğrenci Performansının Değerlendirilmesi Sorununa İlişkin Temalar

\begin{tabular}{ll}
\hline Tema & Alt temalar \\
\hline & Yönlendiricinin bireysel gözleme dayalı değerlendirme \\
& yapması \\
& Grup sayısı kalabalıklaştıkça objektif olmada zorluk \\
Öğrenci performansının & Grup sayısı kalabalıklaştıç̧a herkesin katılımını sağlamada \\
değerlendirilmesi & zorluk \\
& Grup sayısı kalabalıklaştıkça sessiz kalan öğrenciler olması \\
& Birkaç kişinin daha aktif katılımı, diğerlerini rahatlatabiliyor \\
& Öğrenim hedeflerini paylaşarak çalışmaları, herkesin her şeyi \\
& öğrenmemesi \\
& Değerlendirme formları oturum sonunda teslim edilmediğinde \\
& yaşanan evrak kayıpları \\
\end{tabular}

Aşağıda katılımcıların öğrenci performansının değerlendirilmesinde yaşadıkları sorunlara ilişkin söylemlerinden birkaç örnek verilmiştir:

ÖU4, K: Mesela ben bir gruba girmiştim. 11 'mi 12 kişi miydiler. Dokuz kişi, dokuzu da sakallı öğrenci. Erkeklerin hepsi sakallı. Bir ipucu yok yani. Önlerine isim koyuyorsunuz felan ama. Bir süre sonra işte hani nerelisinle; O işte bilmem Antalyalı olan. O bilmem nereli olan. Çünkü gruptaki kişi sayısı arttıkça ve aynı stil giyinip, aynı stil davrandıkları için yani hani erkekleri mesela ayırt edemiyordum. ... ama, eşit değerlendirmek, veya ne bileyim objektif bir değerlendirme yapmak grup kalabalıklaştıkça zorlaşıyor.

ÖÜ8, E: Hani daha küçük gruplarda daha çabuk öğrencileri tanıma veya onların katılımlarını izleme şansın oluyor. Büyük gruplarda mutlaka birkaç tanesi mesela sessiz kalabiliyor. Yakalıyorsun ama katılımı sağlamak açısından küçük gruplar daha iyi bence.

ÖU5, E: Etkin katılım için şunu söyleyebilirim. 10 kişi varsa bunların içinde bir 3-4 kişi tempocu var, öyle söyleyeceğim. Gerisi onları izliyor. Ve bir süre sonra eğer bu dengeyi çok net oturtturamazsanız zaten, şeyler vardır böyle hani, asalak diyebileceğim tipler. Onların sırtından geçinmeye başliyorlar bir süre sonra. İşte sen bul, sen yap. İşte bilmem ne, falan filan oluyor.

ÖU8, K: Aralarında paylaşabiliyorlar. Mesela ben onu son gruplarda özellikle uyarıyorum. Kendi aralarında sen bunu çalış, sen bunu çalış diye paylaşıyorlarmış. Onu yakaladığım zaman aynı hedefi ikinci oturuma tekrar getirtip tekrar onları verdiğim oldu mesela. Bir kişiye görev vermişler mesela o çalışıp gelmiş. Anlatıyor da anlatıyor. Ama diğerleri hiç katılımcı olmuyor. O zaman aynı hedefi bir daha koyuyorum ben. Senaryo ilerlemiş olsa bile.

ÖU5, E: PDÖ’nün değerlendirilmesi sırasında hocanın oradan ayrılmasına izin vermemek lazım. Hoca çalışmayı bitirecek, değerlendirmeyi yapacak, büyün evrakları tamamlayacak. Çünkü şöyle bir şey oluyor. Bu bir özeleştiridir aslında. Çok işimiz olduğu için, alıyorsunuz bir şeyi mesela. Eğer iyi sınıflamazsanız formlardan bir kısmı bir süre sonra gidebiliyor. Bulamıyorsunuz, işte gördünüz kâğıt yığınının içine girebiliyor falan filan. Bence o işin orada olması lazım. Odaya götürmek olmamalı.

IP2: PDÖ bittiğinde bize sıkıntı olmuyor. Bazı hocaların notları kendileri götürüyor. Evraklar kayboluyor. Tekrar evrakları hazırlayıp hocaya veriyoruz. 
PDÖ yönlendiricisi. Tıp fakültesi öğretim üyeleri araştırma ve ders verme dışında ayrıca sağlık hizmetleri sunma yükümlülüğündedir. PDÖ yönlendiricisi olarak öğretim üyesinin, hem PDÖ dönemindeki üç haftalık oturumları yönetmek, hem de oturumlarda öğrencileri değerlendirmek gibi gereklilikleri vardır. PDÖ yönlendiricisinin sorunlarına ilişkin temalar Tablo 4'de verilmiştir.

Tablo 4

PDÖ Yönlendiricisinin Sorunlarına İlişkin Temalar

\begin{tabular}{ll}
\hline Temalar & Alt temalar \\
\hline PDÖ yönlendiricisi & \\
\hline
\end{tabular}

Sadece oturum esnasında yönlendiriciye ulaşma, bazen sonraki oturuma kadar iletişim kuramama

Tıp fakültesi öğretim üyelerinin araştırma ve ders vermeye ek olarak sağlık hizmeti sunma yükümlülükleri

PDÖ yönlendiricilik eğitimi alan sayısının az olması grupların

PDÖ yönlendiricisinin eşzamanlı ve ders dışı iş yükü çok olması

Aynı dönem içinde kimilerinin üç dört kez görev alırken, kimilerinin neredeyse hiç almaması

Kongre, toplantı gibi durumlarda PDÖ görevini devretmede yaşanan zorluk

Bazen asistanın oturuma gönderilmesi, yönlendirici farklılığ nedeniyle oturumlar arası kopukluk

Üç oturumu bir arada yapma

İkinci ve üçüncü oturumu birleştirme

Yönlendirici olduğunu unutup öğrenci-hoca ilişkisine dönüşen diyaloglar

PDÖ'nün içselleştirilmemesi

Bilgi kaynağı olarak kendini görme

Aşağıda katılımcıların PDÖ yönlendiricisinin yaşadığı sorunlara ilişkin görüşlerinden birkaç örnek verilmiştir:

ÖU4, K: Hevesli yapan bir hoca grubu var mutlaka tabii ki, 100 kişi iyi yapıyor ama diğer 100 kişi de biraz hani yasak savıyor. Angarya gibi geliyor. Ya da hani, işin arasında bir de o çıktı anlamında yani. O kadar işin arasında. Herkesin çok işi var aslında, cerrahların ameliyatları var, dahiliyecilerin hastaları var. Anjiyolar var kardiyologlar için veya diğerleri için.

ÖU8, K: Bir de mesela şöyle oluyor. Hani bazen hep aynı kişilerle döndüğü için. Atıyorum bazen üç tane yaptığım yıllar olmuştur benim. Üç ya da dört yaptığım mesela. Hani onun yerine mesela iki tane yaptığın zaman çok daha keyifli oluyor. Anlatabildim mi yani? Miktarsal da bazen insanın işte bütün o diğer planlarıyla kesiştiği zaman şeyler oluyor. Eşit katılım sağlanmayınca tabii, katılım daha fazla gelebiliyor. Eğitim alanlar sınırlıydı bir de geçmişte.

ÖU4, K: Son dakika aksilikler de çok oluyor. Maalesef öyle şeyler çok oluyor. Oturumları asistanlarına yaptıranlar bile olmuştu mesela hani ayıptır söylemesi. Kendisi katılamıyor ama asistanını gönderiyor. Oysa bu bir ders değil. Bu bir süreç. Çünkü o ekiple siz baştan sona bir iletişim kuruyorsunuz. Birinci oturum, ikinci oturum, üçüncü oturum gibi. Ve en sonunda derse not veriyorsunuz hani. Katılımına, sosyal becerisine, sunumuna her şeyine not veriyorsunuz. Çünkü ve o bir iletişim.

ÖU7, K: Bazı öğretim üyelerinin üç oturumun üçüne de katılma konusunda, zaman ayarlama konusunda sıkıntılar yaşadığını, ya da en azından bize katılamayacaklarını söylediği zamanlar oldu. Büyük çapta da öğretim üyelerinin PDÖ nün tam olarak da anlamını 
kavrayamadıklarından bence kaynaklanan üç oturumu bir arada yapma, veya iki oturumu bir arada yapma gibi, aslında PDÖ'ye uymayan uygulamalar yaptıklarını biliyorum. İlk yıllarda biz titizlikle bunun olmamasına çok gayret ettik. Ama son yıllarda, yani benim ayrıldığım zamandan sonra bu tür uygulamaları sıklıkla duyuyorum. Birleştirilen oturumlar ve PDÖ ruhuna uymayan uygulamaları zaman zaman duyuyorum.

ÖU8, K: Yani üçüncü oturumlar kısa bile sürse mutlaka üç oturum yapılmalı. Ben ikili gruba da girdim. Çok sağlıksız oluyor. Yani, hem öğrenilmesi gereken hedefler açısından, problemler çıkıyor ve şey böyle, biraz hani paldır küldür yapılıyor gibi oluyor. Mesela bazı uygulayıcılar kendi insiyatifleri iki uygulayanlar varmış ama hani bence hep üç olmalı.

ÖÜ8, K: O yüzden üç oturum olmasının böyle de bir avantajı oluyor. İkide biterse mesela o çocuklar bir daha o bilgiye ulaşmaya çalışmıyorlar. Ama üç olursa yine işte tekrar getirebilirsin. $O$ biraz esnek bir şey biliyorsun; öğrenim hedefleri yani. Eğer amacına ulaşmamışsa tekrarlatabilirsin.

ÖU5, E: ... Biz mesela iş yaşamında hep diyoruz ki problem çözün. Hep çözün. Bence PDÖ bunların yollarından bir tanesi. Eğer efektif kullanııırsa. ... Bunu yapabilmek içinde aslında insanların rahat hareket etmeye ihtiyacı var. Yanlış yaparsa yapacak, yani bazen hocalar bunu yapıyorlar işte. ... Hani yönlendirici rolünü unutuyor, bir bakıyorsunuz bir süre sonra öğrenci hoca ilişkisine dönüyor iş. ... Çünkü oradaki amaç şey değil, cevabı söylemek değil. O kendi bulacak onu. Ama ben hala eğiticiler kısmında da bunun içine sindirilmesinin, ne diyeyim içselleştirilmesinde sıkıntı olduğunu düşünüyorum.

ÖÜ8, K: Bazı öğretim üyelerimiz, hani bunun içinde klinik branşlar da olabiliyor ama temel bilimler de olabiliyor. İkisini de duydum ben yani farklı farklı öğretim üyelerinden. Bilgi kaynağı olarak kendileri oluyorlar ve konuyu anlatıyorlar. Yani hatta bunun doğal olduğunu düşünen hocalar da var. O zaman PDÖ hedefine ulaşmamış oluyor.

Z kuşağı öğrenenleri ve bu öğrencilerin kaynak ve kütüphaneye erişimleri. 1995 ve sonrasında dünyaya gelmiş bireyler "Z kuşağı" olarak adlandırılmaktadır. Bu nedenle PDÖ odalarında kitaplığa ek olarak internet bağlantılı bir bilgisayar da bulunmaktadır. Öğrenciler üniversitenin çevrimiçi kütüphanesinden tıp alanında pek çok temel kitabın ve uygulamanın elektronik formatına ulaşabilmektedirler. Z kuşağ öğrenenleri ve sorunlarına ilişkin temalar Tablo 5'de sunulmuştur.

\section{Tablo 5}

\section{Z Kuşă̆ Öğrenenler ve Sorunlarına İlişkin Temalar}

\begin{tabular}{ll}
\hline Tema & Alt temalar \\
\hline & $\begin{array}{l}\text { Öğrenmede dijital materyalleri, görsel işitsel öğeleri kullanmayı } \\
\text { tercih etmeleri }\end{array}$ \\
Basılı kaynaklar yerine elektronik kaynak sorgulamaları \\
$\begin{array}{l}\text { ögrencilerin kaynak ve } \\
\text { kütüphaneye erişimleri }\end{array}$ & Bilimsel kaynaklar yerine hızlı ve özet bilgi içerenleri tercih etmeleri \\
& $\begin{array}{l}\text { Oturum esnasında kütüphanedeki kitaplar yerine web sitelerini tercih } \\
\text { etmeleri }\end{array}$ \\
& Sinıftaki bilgisayar yerine cep telefonlarını tercih etmeleri \\
\hline
\end{tabular}

Aşağıda z kuşağı öğrenenleri ve onların kaynaklara erişimlerine ilişkin katılımcı görüşlerinden birkaç örnek verilmiştir:

ÖU4, K: Bir de teknoloji çağı bu çăg. Ve mümkün olabildiğince de öğrencilerin şeklinden düşünmemiz lazım. Onlar dijitale doğan bir nesil. Bizim gibi düşünmüyorlar yani. Mesela illa dersi kaydetmek istiyorlar. Dersi kaydetmeye kızıyor hocalar. Hiç kızmıyorum ben. Direkt dersimi ellerine veriyorum hatta. 
ÖU4, K: ... gelip mesela benim kitaplarıma bakmak istediler. Onların elektronik versiyonu var $\mathrm{m} 1$ dediler. Hemen elektronik soruyorlar yani. Kitabı oradan alıp bakmak istemiyor yani. Diyor ki mesela kütüphanenin elektronik kısmından erişebiliyor muyum diye soruyor yani. Öğrenciler tamamen şeyler yani, teknoloji düşkünüler.

ÖU4, K: Mesela laptoplarıyla çıkarıp, kalp seslerini çıkaran grup oldu mesela bana. Kalp hastalı̆̆ının sesini mesela internetten indirip laptopundan bize dinlettirmişti.

ÖU5, E: Dersliklerdeki kaynakların güncellenmesi ve çeşitlenmesinde sorun var. ... Birçok öğrenci bunu hani işte cep telefonunu kullanarak interneti kullanarak bunu kompanse etti açık söylemek gerekirse. Ve çok da doğru bir şey bence. Yanlış bir şey değil. Çünkü en güncel videoya oradan ulaşıyor. Ha biz orada da bir yönlendirme yapıyoruz, çünkü internet olumlu olumsuz bir sürü bilginin olduğu yer. ... Ellerinde, nasıl söyleyeyim, internet gibi bir şey olduğunda, yani cep telefonu bilgi kaynağı olarak kullanıldığında, basılı kaynağa yönlendirmekte zorlanıyoruz çok açık söylemek gerekirse. Çünkü bilmeyen biri olarak; yani çok daha sıkıştırılmış bilgiyi almak daha doğru; hapı yutmak daha doğru. Yani hap yapımında kullanılacak malzemeleri almaktansa, hapı almak daha doğru geliyor. Daha cazip geliyor onlara.

ÖU7, K: Teknik altyapı aslında internet bağlantılı bilgisayarların olması güzel. Oradan öğrenciler şey yapıyor ama işte teknoloji ilerledikçe aslında yavaş yavaş onların bile kullanımı azaldı. Çocuklar hemen cep telefonlarına saldırdı. Tabii bu aslında yönlendiricinin uygun kaynak bulma konusunda öğrencilere yol göstermesini bazen engelliyor. Çünkü zaman dar, çok öğrenci var. Hani bazen gerçekten kitaba bakmak, bilgisayarı açmak, oradan taramaktansa anında ellerindeki telefonlardan bilgi arayışı yapabiliyorlar. O konuda ben kendi adıma çok sık uyarılarda bulunuyordum öğrencilere. Uygun kaynak bulma konusunda çok iyi bir yöntem olmadığını, ama bir bakıma da işleri çabuklaştırıyor, onu da kabul etmek lazım.

ÖU4, K: Sınıftaki bilgisayarlar yeterli bence. Internete de bağlı olduktan sonra, zaten hayat internet biliyorsunuz. En son telefonlarından her şeyi gösteriyorlardı bize. Büyüme eğrisi, büyüme eğrisi hocam işte, Hani oraya bile tenezzül etmiyorlar yani. Ekrana bile. 


\section{Mevcut Sorunlara Teknoloji Destekli Çözüm Önerileri}

Çevrimiçi ortamların tek başına ve yüz yüze ortamlarla birlikte kullanımı. $\mathrm{Bu}$ konuda öğretim üyelerinin farklı görüssleri bulunmaktadır. Kaynak ve materyal paylaşımı konusunda çevrimiçi ortamların kullanılabileceğine ilişkin görüşler Tablo 6'da sunulmuştur.

Tablo 6

Tek Başına veya Yüz Yüze Ortamlarla Birlikte Çevrimiçi Ortamların Kullanılmasına İlişkin Temalar

Tema Alt temalar

Çevrimiçi ortamların tek başına ve yüz yüze ortamlarla birlikte kullanımı

Genç kuşak öğrenenler buna daha yatkın oldukları için çevrimiçi yürütülmesini tercih edebilirler

Zaman planlaması açısından daha uygun olabilir

Olumlu tutuma sahip olanlar

Kâğıt tüketimi azalır

Yüz yüze buluşmada yaşanan zorlukların önüne geçilebilir

Hâlihazırda öğrencilerle whatsapp gruplarını kullananların varlığı

çok yoğun çalışan branş hocaları veya genç kuşak hocalar tercih edebilir

Kaynak ve materyal paylaşımı açısından etkili olabilir

Tartışmaların yüz yüze ortamda daha aktif ve etkili olacağını

düşünenler

Olumsuz tutuma sahip olanlar Yüz yüze iken her öğrenciyi anlık görebildikleri için kimlerin katılıp kimlerin katılmadığını daha net ayırt edebileceğini düşünenler

Çevrimiçi olduğunda öğretim üyesinin öğrencilere rol model olmasının zorlaşacağını düşünenler

Aşağıda çevrimiçi ortamların tek başına veya yüz yüze ortamlarla birlikte kullanılmasına ilişkin katılımcı görüşlerinden birkaç örnek verilmiştir:

ÖU4, K: Bence elektronik olmasını ben doğru buluyorum öğrencilere. ... İstedikleri uygun bir saati bulabilirler mesela. Yüz yüze iken, her saatte öğrenciler buluşamıyor, sınav kargaşası oluyor. Mesela daha uygun bir saati, herkesin uygun olduğu bir saat, hocanın da onların da uygun olduğu bir saat olabilir. Bulabilirler yani. $\mathrm{O}$ da serbest bir şey bence.

ÖU8, K: Bu arada öğretim üyeleri hazır değil bence. Bir çok öğretim üyesi. Bir grup isteyebilir. Hani daha en en son jenerasyonlar. Bir de belki çok yoğun çalışan cerrahi branşlar, ya da ne bileyim böyle hani daha bunlara zaman ayırırken daha zorlanan bir grup öğretim üyeleri var. Onlar bunu tercih edebilirler diye düşünüyorum.

ÖU3, E: Yeteri kadar samimi olmazdı diye düşünüyorum. Uygun olmazdı diye düşünüyorum. Çünkü orada siz öğrencinin nasıl okuduğunu, nasıl karar verdiğini görüyorsunuz. Online sistemde kameralı bir sistemde göremezsiniz ki, olmaz yani. Daha sicak bir ortamda gerçekleşiyor. ... PDÖ oturumlarından sonra kaynaklar tabii ki online paylaşılabilir. Bunlar yapılabilir ama, tartışmalar online olmaz tartışmalar. Kendi aralarında olacak. O sıcak tartışmaları görmek çok güzel. Kiminin sesi yükseliyor, kiminin alçalıyor. Kimi onay vermiyor. Kiminin yaptıklarından başkaları yol çıkartabiliyor kendisine. Bence yüz yüze olması en güzeli.

ÖU6, K: Ben aynı etkiyi vereceğini sanmıyorum. Öğrenciler beni ekranlarında görecek ama ben onların yüzlerini göremeyeceksem, bence çok kullanışlı değil. Çünkü onların tepkilerini görmem lazım. Katılımcı olmayanı takip etmek de zor olabilir öyle bir sistemde. 
ÖU8, K: ... Bir çok öğretim üyesi buna dikkat ediyor. Derslerin olduğu gün çok daha kendini ne bileyim işte kılık kıyafetine kadar dikkat diyorsun. Davranış paterninle de örnek olmaya çalışıyorsun. Hani mesela onu uzaktan sağlamanın çok doğru olduğunu, yani çok iyi yapılabileceğini düşünmüyorum. Rol modellikte biraz daha sıkıntı olabilir bence.

ÖU8, K: Yani ben biraz daha temas, görmek, konuşmak, Yani mesela ben online ders açısından da çok sıcak bakamıyorum ama, denenebilir tabii. Ama ilk etapta çok gönüllü değilim tabii. Öyle söyleyeyim. Kendim online ders vermeye. Mesela başka konularda da bize geliyor derneklerimiz aracılığıyla felan. Ben daha böyle etkileşimli şeyler, yani onun için PDÖ'yü ben daha çok seviyordum. Etkileşimli şeyleri seviyorum ama bilemedim şimdi. Hani deneyebilirim hani bir zorunluluk olursa ama hani kendi tercihimi dersen hani, görsel seyretmeleri evet ama tamamen online, yani uzaktan eğitim gibi olmasında bende soru işareti var.

Senaryoların çoklu ortam destekli biçimde sunumu. Belgelerin çevrimiçi ortama taşınması ve senaryoların çoklu ortam destekli biçimde sunulmasına ilişkin öğretim üyelerinin farklı görüşleri bulunmaktadır. Bu görüşler Tablo 7'de sunulmuştur.

Tablo 7

Senaryoların Çoklu Ortam Destekli Biçimde Sunulmasına İlişkin Temalar

\begin{tabular}{ll}
\hline Tema & Alt temalar \\
\hline \multicolumn{2}{l}{ Senaryoların çoklu ortam destekli biçimde sunumu } \\
\hline & Kâğıt kullanımının azalması \\
& Karar vermeye dayalı elektronik senaryolar olduğunda kişiler pek \\
çok defa deneme yaparak öğrenme sağlayabilirler & Genç doktorlar yeni imkânlarla yetişmeli \\
& Görsel ve işitsel öğelerle desteklenebilmesi \\
\hline \multirow{2}{*}{ Olumsuz tutuma sahip olanlar } & Eğer projeksiyon olmayacaksa herkes sınıftaki monitörden \\
& izleyecekse etkili olmayacağını düşünenler \\
\hline
\end{tabular}

Senaryoların çoklu ortam destekli biçimde sunulmasına ilişkin aşağıda bazı katılımcı görüşlerine yer verilmiştir:

ÖU4, K: Daha önce, sağlık bakanlığının aile hekimliği animasyon uzaktan eğitim programı gibi bir projesinde branşımla ilgili senaryoları kontrol etmiştik biz ekip olarak. ... O mesela soruyordu. Bundan sonra ne zaman kontrole çağırılmalıdır bu hasta? Bildin, bildin. Bilemedin başa dön diyordu. Böyle esprili bir senaryo akışı vardı. Güzeldi yani.

ÖU6, K: Eğer projeksiyon olmayacaksa monitörden izleyeceklerse çok etkili olacağını düşünmüyorum. Küçük bir ekrandan hepsinin detayları göreceğini sanmıyorum. Öğrencileri grup grup çağırıp birkaç defa izlettirmek gerekebilir. O da çok sıkıcı bir yol hem hoca için hem diğer öğrenciler için. Başkalarını beklemek ölü zamanlar yaratacaktır.

ÖU4, K: Böyle bir stille yetişmeliler yani genç doktorlar. ... O yüzden bu online işinin doğru olduğunu düşünüyorum açıkçası ben. Giderek ona doğru gidiliyor.

Çevrimiçi değerlendirme. Öğretim üyeleri, yüz yüze PDÖ uygulamalarında aynı esnada hem yönlendirici olma hem de gözleme dayalı değerlendirme yaparak öğrencilerin katılım ve katkılarını belirlemektedir. Mevcut sistemde yürütülen değerlendirmeler kâğıtlar üzerinde olup idari personele iletilmekte ve onlar tarafından sisteme işlenmektedir. Değerlendirmenin çevrimiçi yapılmasına ilişkin görüşler Tablo 8 'de sunulmuştur. 
Tablo 8

Çevrimiçi Değerlendirmenin Yapılmasına İlişkin Temalar

\begin{tabular}{ll}
\hline Tema & Alt temalar \\
\hline & Ne kadar katılıp ne kadar sunduğunun objektif biçimde görülebilmesi \\
& Kriterlerin objektif olması \\
Çevrimiçi değerlendirme & Değerlendirme formlarının kalıcı ve sistematik biçimde saklanması \\
& Değerlendirme verilerinin hızlı analiz edilebilmesi \\
\hline
\end{tabular}

Aşağıda değerlendirmenin çevrimiçi yapılmasına ilişkin bazı katılımcı görüşlerine yer verilmiştir:

ÖU8, K: ... tabii daha ideal, nesnel değerlendirilebilir. Daha iyi objektif kriterlerle olabilir.

IP1: PDÖ bittikten sonra değerlendirme notlarını listeliyorum sınav merkezine bildiriyoruz ve değerlendirmeler yapılıyor değerlendirmeler ekrandan bize verilen formlar üzerinden oralara işliyoruz öğrencilerin ve öğretim üyelerinin senaryo hakkındaki düşünce bilgileri. Word belgesine form olarak göndermişler onun üzerinde artı eksi koyup, PDÖ kurul başkanı hocamıza gönderiyoruz.

IP2: PDÖ tarihleri belli olduktan sonra evrakları hazırlamak, öğrencilerin grup listesini hazırlamak, ona göre duyuru yapıp en son ders bittiği zaman da evrakları toplayıp dosyalamak burada yaptıklarımız arasında.

PDÖ yönlendiriciliği. PDÖ uygulamalarını, PDÖ yönlendiriciliği konusunda eğitim alan öğretim elemanları yürütmektedir. Güncel yönlendiricilik eğitiminde PDÖ yönteminin özellikleri, grup dinamikleri ve senaryo yazımı gibi konular bulunmaktadır. PDÖ yönlendiricilerinin sorunlarına ilişkin temalar Tablo 9' da sunulmuştur.

Tablo 9

PDÖ Yönlendiricilerinin Sorunlarının Çözümüne İlişkin Temalar

\begin{tabular}{ll}
\hline Tema & Alt temalar \\
\hline & Bilgiyi sunan olmamak için gereken deneyim, uygulama ve örnek \\
& soruların paylaşılacağı bir platform kurulabilir \\
& Yönlendiricinin motivasyonunu yükseltmek için örnek uygulamalar \\
& izlettirilebilir \\
PDÖ Yönlendiriciliği & Diğer yönlendiriciler veya pdö kurulu ile iletişimde kullanılacak bir \\
& platform kurulabilir \\
& Çevrimiçi olduğunda yönlendirici bilgiyi sunan olmayı bırakabilir
\end{tabular}

Aşağıda katılımcıların PDÖ yönlendiriciliğine ilişkin sorunların teknoloji destekli biçimde nasıl çözülebileceğine ilişkin önerilerinden bazıları verilmiştir:

ÖU1, K: Diğer yönlendiricilerle tabii ki iletişime geçiyorum. Ne konuda ve nasıl diye. En azından sınıf atmosferini, ne oldu ne bitti onları paylaşıyoruz. Yaşadığımız bazı sıkıntılar oluyor. Onu gerek diğer PDÖ yönlendiricileriyle gerekse fakülte yönetimiyle paylaşıyorum.

ÖÜ8, K: Zaman zaman iletişime geçiyorum. Mesela ilk uygulamalar sırasında özellikle yani yönlendiricilerden çok kurulla iletişime geçtiğim, sorduğum şeyler oluyordu. Yani aklıma takılan ya da uygulamada mesela tam doğru olmadığını düşündüğüm, ya da ben uygularken hata yaptığım şeyleri soruyordum kurul başkanlarına. Kendi aralarımızda da mesela PDÖ’yü uygulayan hocalarımızla Senaryoyla ilgili konuşmalar yapıyoruz. Mesela işte bu senaryo çok güzel kurgulanmış. Bunda işte çok çabuk çözüyorlar. Bunda şöyle detaylar var gibi yapıyoruz. 
Ama hani biliyorsun biz daha çok eğitimle ilgili gruplar birlikte oturduğumuz için bu yapıllyor bence.

ÖU5, E: Yani bu şunu demek istiyorum bakın, aslında diyelim ki ben hani şeyden onlinedan çok hoşlanmıyorum. Uzaktan eğitime çok inanmıyorum vs vs. kişisel olarak inanmayabilirsiniz, ama dünya oraya gidiyor. Bütün işler oraya gidiyor. En basit bir anket formunu bile internetten dolduruyoruz artık. Yani böyle bir şey varken kâğıtta 1 srar etmek doğru değil. Söylemeye çalıştığım şey o. Ha mutlaka sorunlar olacak, olmaz diye bir şey yok. Mükemmel falan diye demiyorum. Öyle bir iddiam falan yok. Ama onu da o çerçeve içinde değerlendirmek lazım, benim düşüncem $\mathrm{o}$.

ÖU4, K: Hocalar çok hazır mı emin değilim yani. Online'da öğrenci, yani öğretim üyesi daha çok böyle, ımmm, tam bir facilitatör olacak yani. Kolaylaştırıcı olacak. Tamamen hani o anda insan böyle bir şeyler anlatma hissine giriyor. Çünkü öğrenciler soru soruyor size. Siz de hani bilmiyorum demektense biraz yandan, sağdan, soldan hani kendi çerçevenizle anlatma hissi oluşuyor. Online olursa daha doğru olur. Yani hedefe kilitlenirsiniz. Siz onlara kolaylaştırıcı olursunuz. Onlar bulurlar eksiklerini saptarlar. Ve kendilerinin neye ihtiyacı var onu öğrenip, çalışıp size işte geri sunarlar veya bildirirler. Bence daha doğru olur öğretim üyesinin rolü bu online ortamda diye düşünüyorum. Belki giderek öğretim üyesi değil de bir standart değerlendirici gibi ekip bile olabilir yani hani şu anda hayal gibi belki ama.

Günümüz genç kuşağı ve e-kaynaklar. Üniversite kütüphanesi, mezuniyet öncesi tıp eğitimi alan $\mathrm{Z}$ kuşağı öğrencilerine yönelik pek çok elektronik kaynak sunmaktadır. Öğrencilerin e-kaynakları kullanımına ilişkin temalar Tablo 10' da verilmişstir.

Tablo 10

\section{Z Kuşağı Öğrenenler ve e-Kaynakların Kullanımına İlişkin Temalar}

\begin{tabular}{ll}
\hline Tema & Alt temalar \\
\hline & $\begin{array}{l}\text { Günümüz öğrencilerinin çevrimiçi öğrenmeye zaten hazır } \\
\text { Günümüz genç kuşağı ve e-kaynaklar }\end{array}$ \\
& Kaynak güncellemesi çok daha pratik ve kolay yapılabilir \\
& Görsel-işitsel ve elektronik paylaşımlar yapılması mümkündür \\
\hline
\end{tabular}

Aşağıda katılımcıların yeni kuşak öğrenenlere ve e-kaynak kullanımına ilişkin bazı görüşlerine verilmiştir:

ÖU4, K: Günümüz öğrencileri elektronik paylaşıma veya online paylaşıma bence çoktaaan hazırlar. Zaten öyle istiyorlar yani. Öyle çalışıyor kafaları yani.

ÖU5, E: Ben olumlu bakarım. Çok açık söyleyeyim, çünkü online'a yarı online'a döküldü zaten, özellikle kaynak kullanılması konusunda. Yani burada çok önemli bir şey var, bir kere kaynakların güncellenmesi çok daha kolay olur.

ÖU8, K: Yani hani ben her ne kadar kağıt kalem seviyorum desem de hani görmeleri seyretmeleri, biliyorsun şimdiki nesil biraz daha böyle o tarz şeyleri görsel ve elektronik şeyleri daha çok sevdikleri için belki daha iyi olabilir yani onlar adına daha iyi olabilir. ... Onlar zaten herseyi online yaşıyorlar. Yani onlarda sıkıntı olacağını düşünmüyorum. Onların tercihine brrakı1ırsa onlar bunu tercih edebilirler.

\section{Sonuç ve Tartışma}

$\mathrm{Bu}$ çalışmada PDÖ sürecinin yürütülmesinde yaşanan sorunları belirleyebilmek için PDÖ yönlendiricileri ve idari personel ile görüşülmüş ve elde edilen bulgular paylaşılmıştır. Mevcut sorunlar ve çözüm önerileri beş başlık altında ele alınmıştır. a) fiziksel mekânların ve PDÖ yönlendiricilerin planlanması ve organizasyonu, b) senaryoların kâğıda basılı formda sunulması, c) öğrenci performanslarının objektif 
biçimde değerlendirilmesine yönelik sıkıntılar, d) PDÖ yönlendiricilerinin iş yükü, istekli olma durumları ve yönlendiricilik yaparken dikkat etmeleri gereken rollerin bazen unutulması ile e) günümüz z kuşağı öğrenenleri, bu öğrenenlerin kaynak ve kütüphaneye erişirken daha çok web temelli kaynaklara yönelmeleri şeklinde sorunlar ortaya konulmuştur.

T1p eğitiminde uzaktan eğitim ve e-öğrenme konularında yapılan çalışmaların olumlu sonuçlar vermesi (Han, Resch \& Kovach, 2013), tıp eğitiminin belirli bir yerinde bu teknolojilerden yararlanma eğilimini arttırmıştır. Zira öğrenci sayılarının oldukça kalabalık olması, eğitici-öğrenci arasında iletişim eksikliğinin bulunması, yoğun ders programlarının getirmiş olduğu bilişsel yük ve amfilere sıkışan öğrencilerin öğrenme güçlüklerine bakıldığında alternatif yöntemlere ihtiyaç duyulduğu söylenebilir (Sezer, Odabaşı \& Abay, 2014). Ancak e-öğrenmenin tıp eğitimi programına nasıl yerleştirileceği, hangi konuları kapsayacağı sorularına hala yanıt alınamamış olmakla birlikte Tıp fakültelerinde teknik altyapı yetersizliğine ek olarak, web tasarımı, grafikçi gibi alan uzmanlarının azlığı da elektronik uygulamaların başarıya ulaşmasını etkilemektedir (Gürpınar, 2012).

$\mathrm{Bu}$ gelişmeler 1şığında PDÖ yöntemi de elektronik ortama entegre edilmeye (ePDÖ) çalışılmaktadır. Senaryoya ek olarak sunulan tetikleyici görsel ve resimler (örn. akciğer filmi, pataloji sonuçları vb.) (Azer, 2007b), interaktif video ve dijital kütüphaneler (Vasiliou, Ioannou, Arh, Zaphiris, \& Klobučar, 2013) şeklinde elektronik ortama taşınmaktadır. Bu uygulamalar öğrenci öğrenmelerini teknoloji ile aktif biçimde desteklese de, e-PDÖ'nün tasarım ve uygulama açısından en iyi biçimde uygulanmasına yönelik olarak kuramsal bir çerçeve bulunmamaktadır. Kimi zaman tamamen çevrimiçi ortamda yürütülen PDÖ süreçleri yüz yüze tartışma oturumlarıyla desteklenmekte, kimi zaman da yüz yüze yürütülen senaryonun ardından tartışmalar çevrimiçi ortamda gerçekleştirilerek karma (blended) ortamlar oluşturulmaktadır. Doğru teknolojiyi seçmek ve kurmak, onunla e-PDÖ sürecini yürütebilmeyi öğrenmek ve ihtiyaç olduğunda işe koşmak PDÖ yönlendiricileri için zor olduğu kadar öğrenciler tarafından da benzer süreçlerin öğrenilmesini ve kabulünü gerektirmektedir. Jawaid \& Aly (2014) e-PDÖ’yü; e-posta veya sanal öğrenme ortamları aracılığıyla dağıtılan örnek durum/senaryolar olarak tanımlamaktadır. Öğrenciler e-PDÖ yönteminde, birbirleriyle ve yönlendirici ile sohbet odaları, forumlar, e-posta veya interaktif beyaz tahta uygulamaları ile iletişim ve etkileşim içinde bulunurlar (Jawaid \& Aly, 2014). e-PDÖ uygulamalarında, hem probleme ilişkin materyal ve kaynaklarının paylaşımında, hem de iletişim için kullanılan ortam olarak senkron (sohbet-MSN, Whatsapp) ve asenkron (eposta, blog, wiki) araçlar (Vasiliou vd., 2013), ve bunları bir arada barındıran öğrenme yönetim sistemlerinin (Blackboard, Moodle, TopClass) tercih edildiği belirtilmektedir.

Gündüz, Alemdağ, Yaşar \& Erdem (2016), PDÖ yöntemi için tasarlanacak ideal bir öğrenme ortamını oluşturmada Jonassen (1999) tarafından ortaya konulan yapılandırmacı öğrenme ortamlarının tasarımı modelinden yararlanmışlardır. $\mathrm{Bu}$ modelin de odak noktasının problem ve ögrenen olduğunu, öğretmenin bu modelde bir rehber olduğunu, yönlendirici dönütlerle süreci yönettiğini ve öğrenenin kendi anlamlarını inşa etmesi konusunda cesaretlendirilmesi gerektiğini belirtmişlerdir (Gündüz vd., 2016). Ayrıca öğrenme düzeyi ve öğrencilerin kendilerini rahat hissetmeleri açısından geliştirdikleri e-PDÖ ortamının etkili ve başarılı olduğunu belirtmişlerdir (Gündüz vd., 2016). Kim ve Kee (2013), e-PDÖ uygulaması için 
geliştirilecek modelin (1) öğrenme sürecinde bireysel akıl yürütmeyi ve bireyin kendi öğrenmesini yönetmesini desteklemesi, (2) öğrenenlere gerçekçi ve iç içe geçebilecekleri örnek olay/senaryolar sunması gerektiğini belirtmektedir.

e-PDÖ uygulaması, öğrenmeyi sınıf duvarları dışına çıkarması bakımından fiziksel mekan ve yönlendirici organizasyonu probleminin çözümü noktasında işe koşulabilecek önemli bir seçenektir. Çünkü Tıp fakültelerinde görevli öğretim elemanları eğitim ve araştırma görevlerine ek olarak hizmet görevi de üstlendikleri için zaman planlaması yüz yüze PDÖ yönteminde oldukça zor olmaktadır. Kendilerine uygun bir zaman dilimi içerisinde öğrenci grubuyla internet üzerinde bir araya gelmeleri, PDÖ’nün yüz yüze yapılması durumunda ilgili saatte belirlenen fiziksel mekânda bulunma zorunluluğunu ve o anki zihinsel bölünmeyi ortadan kaldırarak oturumun daha etkili sürdürülmesine imkân sağlayabilir. Fiziksel mekân gereksinimi literatürde de dile getirilmiştir (Demirören \& Demirel, 2006). Azer (2007a) yönlendirici sayısının az, öğrenci sayısının fazla olması nedeniyle 19 kişiden oluşan gruplarda PDÖ oturumları yapıldığını belirtmektedir. Son yıllarda öğrenci sayılarının hızla artmasıyla daha çok sayıda PDÖ yönlendiricisine ihtiyaç oluşmaktadır (Musal vd., 2016). Bu durum öğretim üyelerinin iş yükünü daha da arttırmaktadır. e-PDÖ uygulamasında daha az öğretim üyesi ile süreci yönetmek mümkündür (Kim \& Kee, 2013).

Öğrenme çıktıları açısından bakıldığında e-PDÖ uygulamaları öğrenenlerin bilgi edinmelerini, eleştirel düşünmelerini ve klinik akıl yürütme becerilerini destekler (Akt. Kim \& Kee, 2013; Şendağ \& Odabaş1, 2009, Maldonado, 2011). Gavgani vd. (2015)'in yaptıkları meta analiz çalışmasında etkililiği ve klinik akı1 yürütme becerisine katkısı bakımından dijital ve kâğıt-kalem temelli senaryo sunumu arasında fark olmadığı bulunmuştur. Ancak öğrencilerin \%73’ü dijital senaryolardan daha fazla memnun olmuşlar ve dijital senaryoları kullandıklarında \%90 oranında zamandan kazandıklarını belirtmişlerdir (Gavgani vd., 2015).

Yararları açısından bakıldığında e-PDÖ uygulamalarında öğrenen zaman ve mekândan bağımsız olarak, ne zaman, ne konuda nasıl çalışacağını kendisinin planladığı esnek öğrenme firsatlarına sahiptir (Valaitis vd., 2005; MacDermid vd., 2006; Akt. Kim \& Kee, 2013). Bunun yanı sıra senkron olarak da yönlendirici ve akranlarıyla iletişime ve etkileşime girdiği ortamların sunulması daha yararlıdır (MacDermid vd., 2006; Boling, Hough, Krinsky, Saleem, \& Stevens, 2012; Gould vd., 2015). Kim \& Shin (2014), e-PDÖ ortamında öğrenme ve iletişim araçları olarak; sohbet, tartışma forumu, veritabanları, dosya yükleme ve indirme seçenekleri, dışarı web siteleri için bağlantı adresleri koymuşlar ve şu işlevsel özelliklerin bulunması gerektiğini özellikle vurgulamışlardır: a) tekrar erişilebilen video ders sunumları ve otomatik sınavlar, b) konuya ilişkin güvenilir web adresleri ve c) diğer grupların erişemeyeceği her grubun kendine özel paylaşım panoları. Web siteleri, çevrimiçi tartışma platformları gibi asenkron (eş-zamanlı olmayan) yöntemler, öğrenenlerin öğrenmede aktif rol almalarına imkân tanımakta ve onlara daha esnek zaman dilimlerinde öğrenme süreçleri sunmaktadır (Howatson-Jones, 2004). Grup kararları vermede asenkron yöntemlerden ziyade sohbet gibi senkron (eş-zamanlı) platformların daha etkili olduğu söylenmektedir (Valaitis vd., 2005). Bu ortamlar sınıf içerisinde kendilerini rahatlıkla ifade edemeyen, soru sormaktan veya konuşmaktan çekinen, özgüveni düşük öğrenciler için de büyük bir iletişim firsatı sağlamaktadır (Hussain, Mamat, Salleh, Saat \& Harland, 2007). Diğer taraftan e-PDÖ yönteminde öğrenenlerin üzerlerinde daha fazla iş yükü algıladıkları 
söylenebilir, özellikle çevrimiçi okuryazarlık becerileri yeterince iyi olmayan öğrenenlerin bu becerilerini de geliştirmeleri gerekmektedir (Valaitis vd., 2005).

PDÖ senaryolarının sunumunda çoklu ortam öğelerinin kullanımı; yüz yüze PDÖ sürecindeki kağıt tüketimi sorununa (Demirören \& Demirel, 2006) çözüm olmakla birlikte, senaryonun gerçeğe yakın olmasını sağlar, ayrıca kâğıt kalem formatında sunumuna göre öğrenenin senaryo ile daha fazla iç içe geçmesini kolaylaştırır (Persson vd., 2010; Kim \& Kee, 2013). Böylelikle bilgi paylaşımı ve tartışmalar zenginleşir (Keskin, Musal, Tuncel \& Canda, 2014). Örneğin çoklu ortam tabanlı bir senaryo sunumu, hastanın, hasta yakınlarının tepki ve durumlarını aktarmada metin tabanlı sunuma göre çok daha etkilidir (Persson vd., 2010). Senaryoların sunum şekline göre (kağıt kalem tabanlı veya dijital) sunum süresi, eğitim, maliyet ve derslerin çekiciliği değişmektedir (Gavgani vd., 2015).

Yapılan araştırmalarda senaryoların çoklu ortam olarak sunumlarında daha çok videonun tercih edildiği görülmektedir (Kim \& Kee, 2013; Persson vd., 2010). Video kayıtları metin tabanlı senaryo sunumuna göre duruş (posture) ve hareketleri çok daha etkili biçimde göstermektedir (Balslev, De Grave, Muijtjens, \& Scherpbier, 2005). Kim \& Shin (2014) de benzer şekilde video tabanlı problem senaryosu sunumlarında hastalar daha gerçekçi ve bütüncül biçimde göründükleri için e-PDÖ programlarının başarılı olduğunu belirtmişler, bu videoların ayrıca geleneksel PDÖ yönteminde de kullanılabileceğini belirtmişlerdir. Diğer taraftan, Ghanchi vd. (2013), PDÖ yönteminde metin tabanlı sunumdan video tabanlı problem senaryosu sunumuna geçtiklerinde dijital yerliler olarak tanımladıkları öğrenenlerin videolar ile daha fazla ilgilenmelerini beklemişler ancak öğrenenler metin tabanlı sunumu tercih ettiklerini belirtmişlerdir. Aynı çalışmada PDÖ yönlendiricilerinin de görüşü alınmış ve onlar iki yöntem arasında (metin/video tabanlı) grup tartışmaları, dinamizm ve iletişim becerileri açısından etkililik hususunda fark olmadığını söylemişler, üstelik video tabanlı sunumları daha ilgi çekici bulmuşlardır. Bunun üzerine Ghanchi vd. (2013) video tabanlı sunulacak senaryoların, öğrenim hedeflerini çıkarmada gözlenebilir ipuçları sağlayan problem türlerinde daha seçici biçimde kullanılmasını önermişlerdir. Ayrıca öğrencilerin önce geleneksel yöntemle PDÖ sürecini yaşamalarını, daha sonra video temelli senaryo sunumlarına gidilmesini önermişlerdir (Ghanchi vd., 2013). Turan \& Demirel (2011)'in araştırmasında Tıp Fakültesi öğrencileri PDÖ sürecinde sunumlardan hoşlanmadıklarını ama bu tür vaka örneklerini kendilerini kliniğe hazırlaması açısından sevdiklerini, tıp eğitiminde animasyonları tercih ettiklerini hatta animasyonları arkadaşlarıyla da paylaştıklarını belirtmişlerdir. Lou vd. (2010), öğrenenlerin dikkatini cezbetmek ve motivasyonlarını arttırmak için çevrimiçi öğrenme ortamlarında içeriklerin animasyon veya eğitsel oyunlar gibi ilgi çekici olması gerektiğini belirtmişlerdir (Akt. Vasiliou vd., 2013).

Hasta simülatörlerinin ortaya çıkışı, çoklu ortam destekli klinik vaka simülatörü yazılımı, yeni uygulamalar PDÖ yöntemine yansımış ve metin tabanlı senaryo sunumunun çok ötesinde kullanım alanları ortaya çıkmıştır (Maldonado, 2011; Vasiliou vd., 2013). Örneğin, Ellaway, Poulton \& Jivram (2015) sanal hasta ile karar vermeye dayalı PDÖ (KVD-PDÖ) uygulaması yapmışlardır. Bu uygulama, öğrenenlerin yine bir arada ve yüz yüze olup, yönlendiricinin daha pasif olduğu, etkileşimin grup içinde öğrenenler arasında daha fazla olduğu bir yöntemdir. KVD-PDÖ ile öğrenciler grup olarak verdikleri kararlar çerçevesinde sanal hastayı yönetmekte, bazen karar ağacında 
ölümle sonuçlanan bir yol izlendiğinde; "Tebrikler hastayı öldürdünüz, tekrar deneyiniz" şeklinde bir mesajla karşılaşarak süreç içinde yeni deneme ve öğrenmeler gerçekleştirebilmektedirler (Ellaway vd., 2015). Diğer taraftan, Second Life gibi sanal dünyalarda kurgulanacak karakterler ve senaryolar ile öğrenenler, gerçek yaşam deneyimlerini güvenli ve kontrollü bir ortamda tecrübe edebilirler (Vasiliou vd., 2013).

Çoklu ortam temelli üretilen problem senaryolarının yaygınlaşması, yüz yüze yapılan önceki uygulamalardaki kâğıt-kalem tüketiminin önüne geçilmesi, eş zamanlı olarak fiziksel ortamda yürütülen PDÖ uygulamaları için fiziksel mekân planlamada yaşanan zorlukların ortadan kaldırılması, 21. yüzyıl öğrenenleri olarak hekim adaylarının çevrimiçi ortamları etkin kullanmaları ve her an her yerde öğrenme felsefesi ile öğrenmenin sınıf duvarları dışına çıkarılması e-PDÖ ile beklenen avantajlardır. Ayrıca yüz yüze ortamda küçük gruplar ile yürütülen PDÖ uygulamalarında PDÖ yönlendiricisi konumundaki öğretim üyesinin aynı zamanda gözleme dayalı olarak olarak değerlendirme yapmasında somut verilere ulaşılamazken, düzenlenecek çevrimiçi ortamda hangi öğrencinin ne kadar aktif olduğuna ilişkin doğru ve güncel veriler loglarda kayıtlı olarak tutulacak ve değerlendirme daha sağlıklı biçimde yürütülebilecektir. Katılımcıların her an her yerden kolay ve eşit seviyede erişebilecekleri bir ortamda buluşmaları, grupla bağlarının artması beklenmekte, ayrıca edindikleri deneyimin mesleki gelişimlerine de katkısı olacağı düşünülmektedir.

Yüz yüze yürütülen PDÖ uygulamaları, grup düşünce akışını ve dinamiklerini takip ederek uygun zaman ve miktarda grup dinamiklerine müdahale edebilme, süreç devam ederken öğrencinin katkısını değerlendirebilme gibi beceriler gerektirmektedir (Yıldız-İnanıcı, 2014). Azer (2007a)'ya göre; öğrenci sayısı arttıkça grup dinamikleri etkilenmekte ve öğrencilerin tartışmalara ve öğrenme sürecine katılımları azalmaktadır. PDÖ yönlendiricisi olarak öğretim elemanlarının kolaylaştırıcı ve rehber rolünü unutmamaları oldukça önemlidir (Savin-Baden, 2006; Demirören \& Demirel, 2006; Azer, 2007a). Öğretim elemanları geleneksel yöntemlerde alışkın oldukları lider ve öğreten rollerini PDÖ yönteminde bir kenara bırakabilmeli (Demirören \& Demirel, 2006; Y1ldı-İnanıc1, 2014), öğrencileri aktif öğrenenler olarak görebilmelidirler. PDÖ uygulamalarının verimliliği açısından, yönlendiricilerin daha iyi eğitim almış olmaları, daha fazla PDÖ oturumuna katılmış olmaları, öğrencilerin daha etkin ve eşit düzeyde katılımlarını sağlamaları önemli bir husustur (Demirören \& Demirel, 2006). Yönlendiriciler öğrenenenleri düşünmeye sevk eden sorular sorabilmeli, bilginin nasıl analiz ve sentezleneceğine yönelik yansımalar göz ardı edilmemelidir (Azer, 2007a). Literatüre bakıldığında PDÖ yönteminin "sorgulama" konusunda öğretim üyesini zorladığı görülmektedir (Hussain, Mamat, Salleh, Saat, \& Harland, 2007). Azer (2007a)'ye göre öğrencilerin sordukları açık uçlu sorulara cevap vermekten kaçınarak öğrenim hedeflerini belirlemekten sakınmalıdır. Savin-Baden (2006) yüz yüze ortamda başarılı PDÖ yönlendiricilerinin sözel olmayan ipuçlarını çevrimiçi ortamda kullanamadıkları için e-PDÖ ortamında etkili olamayabileceklerini söylemektedir. Sözel olmayan ipuçları için çeşitli emoji ve ifadelerden yararlanma konusunda kılavuz materyaller sağlanabilir. Diğer taraftan Valaitis vd. (2005), e-PDÖ yönteminde yönlendiricilerin, yüz yüze PDÖ den farklı olarak internet ve çevrimiçi ortamın kullanımı konusunda yeterli düzeyde bilgi ve deneyime sahip olmaları gerektiğini belirtmişlerdir. Bu noktada bilgi gereksinimi olan öğretim üyelerine bir süre teknik destek sağlanması gerekebilir. 
e-PDÖ ortamında öğrenenlerin sözlü ve yazılı katılımları kayıt altına alınarak raporlandığ1 için daha sonra performanslarını objektif ve şeffaf olarak da değerlendirmek mümkündür (Keskin vd., 2014). Yine bu ortamlarda grup içi yürütülen görevlere ilişkin akran ve öz-değerlendirme formları sunularak öğrenenlerin kendilerini ve birbirlerini değerlendirmeleri konusunda da beceri elde etmeleri mümkün kılınabilir (Keskin vd., 2014). Katılımcı geribildirimlerine ilişkin değerlendirmeler hızlı ve analitik biçimde gerçekleştirilip senaryoya ve PDÖ sürecine ilişkin iyileştirmelerin yapılması mümkün olabilir.

Z kuşağı öğrenenleri eğitimin sosyal olmasını ve sınıfta geçirilen zamanın işbirlikli çalışmalara ayrılması gerektiğini düşünmektedirler (May, 2016). Mezuniyet öncesi tıp eğitiminde bilgi ve iletişim teknolojilerinin (BİT) kullanımına yönelik olarak çevrimiçi işbirlikli öğrenme ortamları sağlamak, 21. Yüzyıl öğrenenlerine ilişkin becerilerin kazanılmasında önemli rol almaktadır. Bu ortamların katılımcıların özellikle klinik düşünme/akıl yürütme, problem çözme ve iletişim becerilerini arttırırken, mesleki ve teknik anlamda da gelişimlerine destek olacağı düşünülmektedir. Gürpınar, Zayim, Özenci \& Alimoğlu (2009), bilgisayarı ve/veya sürekli internet bağlantısı olmayan öğrencilerin çevrimiçi ortamlara katılamadıklarını belirtmiştir. Fakülte veya ilgili birimde öğrencilerin kullanımına açık internet erişimli kullanım zamanı esnek bilgisayarlar olmalı, ayrıca kendi donanımlarını getiren öğrenciler için de şarj ve internet bağlantısı için teknik altyapı sağlanmalıdır.

Aktif öğrenenler olarak konuyla sürekli iç içe olabilecekleri, evlerinden webtabanlı yöntemlerle derse devam edebilecekleri, "anında" öğrenebilecekleri ortamları tercih etmektedirler (May, 2016). Bu kuşağın blogları, podcastleri ve Youtube üzerinde öğretim videoları içeren kanalları takip ettikleri ve bilgi kaynağı olarak yararlandıkları görülmektedir. fMRI çalışmalarında genç katılımcılarda oksipital lobun aktif olduğu gözlenmiş ve onların "görsel işleyen" süreçlerinin güçlü olduğu görülmüştür (May, 2016). Benzer şekilde dünyada da çevrimiçi informal öğrenmeye yönelik gelişmeler hız kazanmıştır. Haziran 2012'de Dublin'de düzenlenen bir konferans için biraraya gelen hekimlerin sohbeti esnasında ortaya çıkan FOAM (Free Open Access Meducation) hareketi, Tıp eğitimini açık erişimli yaparak herkes için, herhangi bir yer ve zamanda öğrenme firsatları sunmaktadır (LITFL, 2014). FOAM, platform ve ortamdan bağımsız olarak bloglar, podcastler, tweetler, Google Hangout oturumları, çevrimiçi videolar, metin tabanlı belgeler, fotoğraflar, facebook grupları ve daha pek çok şeyin bütünü olarak dinamik bir koleksiyon gibi (Nickson \& Cadogan, 2014) düşünülebilir. 7/24 erişime açık bu çevrimiçi kaynaklar öğrenenler açısından önemli dokümanlardır. e-PDÖ uygulamalarında öğrenenler öğrenme materyalleri ve kaynaklara kolaylıkla erişebilmektedir (MacDermid, Solomon, Law, Russell, \& Stratford, 2006; Kim \& Kee, 2013). e-PDÖ uygulamaları kaynak arama ve kuramsal bilgi edinmede öğrenenlere büyük kolaylıklar da sağlamaktadır (Gavgani vd., 2015).

Küçük, Kapakin \& Göktaş (2014)'ün araştırmasında Tıp Fakültesi öğrencilerinin \%75'inin akıllı telefon sahibi olduğu ve telefonlarıyla internette vakit geçirdikleri belirlenmiştir. Aynı öğrencilerin mobil cihazların eğitim amaçlı kullanımını kolay ve faydalı olarak algıladıkları ve olumlu yönde tutum sahibi oldukları görülmüştür. Yazarlar tarafından yapılan ancak henüz yayınlanmamış daha güncel bir çalışmada ise 337 Tıp fakültesi 4. Sınıf öğrencisinden \%92'sinin akıllı telefon ve \%82'sinin dizüstü bilgisayara sahip olduğu, \%92'si düzenli internet erişimine sahipken, \%81'inin de mobil 
internet erişimi olduğu görülmüştür. e-PDÖ uygulamaları ile hem öğrencilerin UTEAK standartlarını yakalamaları hem de bilişim teknolojilerinden yararlanma konusunda deneyim sağlamaları beklenmektedir (Keskin vd., 2014).

Son olarak OECD Yetişkin Becerileri Araştırması (TEDMEM, 2016) sonuçlarına bakıldığında yetişkinlerin (16-65 yaş arasındaki grup), teknoloji yoğun ortamlarda problem çözme performansları bakımından lise kademesinden daha az eğitime sahip olanların \%63.1'inin, üniversite mezunlarının \%7.3'ünün temel beceri testini geçemedikleri veya daha önce bilgisayarla hiç etkileşim kurmadıkları görülmüş̧ür. Aynı rapora göre en üst düzey problem çözme becerisine sahip olan üniversite mezunu yetişkin oranı $\% 4.8$ olup Türkiye bu oranla OECD ülkeleri arasında son sırada yer almaktadır. Bu kötü tablo karşısında gerekli tedbirlerin ivedilikle alınması önem arz ettiğinden üniversite öğrencileri ve öğretim üyeleri teknoloji yoğun ortamlarla daha sık iç içe getirilmelidir. Sonuç olarak, e-PDÖ’nün tamamen çevrimiçi olması veya yüz yüze ortamlarla birlikte kullanımı noktasında pek çok olumlu ve olumsuz görüş yer almaktadır. Literatürde standart bir e-PDÖ ortamı modeli görülmemektedir. Araştırmacılara yapılacak öneriler ise; PDÖ sürecindeki tüm katılımcıların görüş ve önerileri alınarak ve kurumun alt yapı olanakları göz önünde bulundurularak, e-PDÖ yönteminin nasıl planlanması ve modellenmesi gerektiğine yönelik çalışmalar yürütülmesi olabilir. 


\section{Summary}

Purpose and Significance: As a frequently used method in medical faculties, PBL is a powerful method in terms of stimulating curiosity among students and trying to investigate the missing information through scenarios by linking basic and clinical medicine. The purpose of this study is to present the current situation and the problematic issues in the PBL process, and to propose technology-based solutions.

Methods: This study was planned by qualitative research method and data were collected with interview approach. The study group of this research consisted of participants from eight faculty members and two administrative staff from Gazi University Faculty of Medicine. All participants are volunteer and they have agreed to record their voice during the interview. Semi-structured interview forms, prepared separately for faculty and administrative staff, were used in the interviews. After the interviews were transcribed, 13.831 words from the instructors and 926 words from the administrative staff were obtained. All of the text is divided into themes by content analysis method.

Results: Problems related to the present situation are collected under five themes. The themes are as follows: physical space and facilitator organization, printed scenarios, the problems while evaluating student performance, simultaneous and out-of-class workload of PBL facilitators, and Generation $\mathrm{Z}$ learners and their access to the sources and library. It is necessary to plan a lot of parallel sessions while creating the small groups in PBL method because of the increasing number of students in medical faculties. This may create difficulties in both planning the physical space and in planning the teaching staff. Students are struggling to fit into existing classrooms, sometimes requiring additional seats. Students are being distributed to the existing groups when their PBL facilitator informs in the last minute that $\mathrm{s} / \mathrm{he}$ will not able to come. Because it is difficult to find someone instead of his/her place. The number of students in the group already in excess is increasing more. In e-PBL applications, both synchronous (MSN-chat, MSN, Whatsapp) and asynchronous (e-mail, blog, wiki) tools for communicating, and usage of the learning management systems (Blackboard, Moodle, TopClass) will finish the obligation of being present at the same place. In this way, the instructors will be able to allocate time to the students at a more convenient time for them. The conditions that force the physical space will be lifted.

Presenting black \& white printed scenarios makes it difficult to be read some of the images (e.g. X-ray, pathology outlines, stains) due to image quality and colors. The consumption of paper is increasing because of the photocopying to all the students and facilitators. Using digital scenarios will reduce both paper usage and will keep information systematically in a transparent and reliable form. In addition, presentation of problem scenarios with multimedia supported items will ensure that the problem situation is more permanent by combining of visual and audio elements. It is possible that the digital scenarios with video, animation and multi-media supported patient simulator software can be more effective and lasting than text-based scenarios.

Assessment of student performance is difficult, as the number of them in the group increases. It is becoming increasingly difficult to balance students who speak and do not 
speak in the group, direct them to proceed with the discussions, and observe and evaluate the students at the same time. It is not possible for students who do not speak in e-PBL. Moreover, when evaluation forms are taken out of the classroom, problems such as loss of these documents can occur. Participation of students in electronic evaluation can be monitored in a transparent and objective way with student logs. At the end of the scenario, they can create their own concept maps with the help of various tools, and can make self-evaluation or peer evaluation on individual reports and ingroup participation. There is no such thing as document loss when the results are kept in the database.

Obligations of medical faculty instructors to provide health services in addition to research and teaching can make it difficult for the PBL to devote enough time. Sometimes the PBL sessions which need to be done three times are completed in two sessions or one session and do not serve PBL purposes. Sometimes, the instructor leaves the facilitator role and teach traditional, and they determine the learning goals themselves and even present them themselves. Guidance resources on roles for PBL facilitators can be presented online. A sample PBL case video can be shared online and faculty members can have an opportunity to watch an ideal PBL facilitator. A discussion or resource-sharing forum can be added where they can communicate with each other and with the PBL committee. Sample questions that lead learners to think can be shared from this platform. An online presentation, video or sources may be available on the use of non-verbal cues in online environments.

Today's learners are known as the Generation Z, and continue to learn out of the classroom. It is seen that, they are active technology users, and their information gathering process is based purely on technology but mostly on the web pages. More professional web-based resources (e.g. podcasts, open online courses, e-books and videos from university's online library) can be shared to avoid reaching to specific resources only through web pages.

Discussion and Conclusions: From the point of view of benefits, e-PBL has flexible learning opportunities for people to make their own plan on what, when and how to study regardless of time and space. As learning and communication tools in e-PBL environment; chat rooms, discussion forums, databases, file upload and download options, web links of reliable web sites, re-accessible video courses and presentations, automated exams, and group discussion boards that are special for each group will make the learners active in their learning process. As 21st-century learners, they develop online literacy skills and can take learning out of classroom walls with anytime and anywhere learning philosophy. 


\section{Kaynakça}

Azer, S.A. (2007a). Medical education at the crossroads: Which way forward?, Annals of Saudi Medicine, 27(3), 153-157.

Azer, S. A. (2007b). Twelve tips for creating trigger images for problem-based learning cases. Medical Teacher, 29(2-3), 93-97.

Balslev, T., De Grave, W.S., Muijtjens, A.M.M., \& Scherpbier, A. J. J. A. (2005). Comparison of text and video cases in a postgraduate problem-based learning format. Medical Education, 39, 1086-1092.

Boling, E. C., Hough, M., Krinsky, H., Saleem, H. \& Stevens, M. (2012). Cutting the Distance in Distance Education: Perspectives on What Promotes Positive, Online Learning Experiences. Internet and Higher Education, 15(2), 118-126.

Davey, L. (1991). The application of case study evaluations. Practical Assessment, Research \& Evaluation, 2(9). Son erişim tarihi: 7.03.2018 http://PAREonline.net/getvn.asp?v=2\&n=9.

Demirören, M. \& Demirel, M. (2006). Ankara Üniversitesi Tıp Fakültesi dönem 2 öğrencilerinin PDÖ uygulamalarının üstünlük ve sınırlılıklarına ilişkin görüşleri. Tıp Ĕ̈itimi Dünyast, 23, 33-40.

Ellaway, R. H., Poulton, T., \& Jivram, T. (2015). Decision PBL: A 4-year retrospective case study of the use of virtual patients in problem-based learning, Medical Teacher, 37(10), 926-934, DOI: 10.3109/0142159X.2014.970627

Gavgani, V. Z., Hazrati, H., \& Ghojazadeh, M. (2015). The efficacy of digital case scenario versus paper case scenario on clinical reasoning in problem-based learning: A systematic review and meta-analysis. Research and Development in Medical Education, 4(1), 17-22.

Ghanchi, N. K., Khan, S., Afridi, A., Sajid, S., Afzal, S., Ahmed, I., Ahmed, R., \& Ghias, K. (2013). Video or paper for delivery of problem-based learning cases?. Medical Education, 47, 1131.

Glesne, C. (2015). Nitel araştırmaya giriş. (5. Baskı). (A. Ersoy \& P. Yalçınoğlu, Çev. Edt.). Ankara: Anı Yayıncılık.

Gould, K., Sadera, W., \& McNary, S. (2015). Comparing changes in content knowledge between online problem based learning and traditional instruction in undergraduate health professional students. MERLOT Journal of Online Learning and Teaching, 11(1), 74-86.

Gündüz, A. Y., Alemdağ, E., Yaşar, S., \& Erdem, M. (2016). Design of a problembased online learning environment and evaluation of its effectiveness. The Turkish Online Journal of Educational Technology, 15(3), 49-57.

Gürpınar, E., Tetik, C., Alimoğlu, M. K., \& Akdoğan, I. (2011). Probleme dayal ögrenimin eğitim yönlendiricileri ve ögrenciler tarafindan değerlendirilmesi. Topluma Dayalı Tıp Eğitimi ve Eğitim Araştırmaları Sempozyumu, 5-7 Mayıs, Antalya.

Gürpınar, E., Zayim, N., Özenci, C. C., Alimoğlu, M. K. (2009). First report about an e-learning application supporting PBL: Students' usages, satisfactions, and achievements. The Turkish Online Journal of Educational Technology, 8(2), 5562. 
Han, H., Resch, D. S., \& Kovach, R. A. (2013). Educational technology in medical education. Teaching and Learning in Medicine, 25(sup1), 39-43, DOI: 10.1080/10401334.2013.842914

Howatson-Jones, L. (2004). Designing web-based education courses for nurses, Nursing Standard, 19(11), 41-44.

Hussain, R.M.R., Mamat, W.H.W., Salleh, N., Saat, R.M., \& Harland, T. (2007). Problem-based learning in Asian universities. Studies in Higher Education, 32(6), 761-772.

Jawaid M., \& Aly SM. (2014). 'E-learning' modalities in the current era of medical education in Pakistan. Pakistan Journal of Medical Sciences, 30(5), 1156-1158.

Jonassen, D. H. (1999). Designing Constructivist Learning Environments. In Reigeluth, C. M. (Ed.), Instructional-Design theories and models, a new paradigm of instructional theory (pp.215-239). New Jersey: Lawrence Erlbaum Associates Publishers.

Karasar, N. (2004). Bilimsel araştırma yöntemi. Ankara: Nobel Yayıncılık.

Keskin, O., Musal, B., Tuncel, P. \& Canda, T. (2014). Dokuz Eylül Üniversitesi Tıp Fakültesinde Elektronik PDÖ Uygulaması Deneyimi. VIII. Ulusal Tıp Eğitimi Kongresi, 7-9 Mayıs, İstanbul.

Kim, K-J., \& Kee, C. (2013). Evaluation of an e-PBL model to promote individual reasoning. Medical Teacher, 35, 978-983.

Kim, J.-H. \& Shin, J.-S. (2014). Effects of an online problem-based learning program on sexual health care competencies among oncology nurses: a pilot study. The Journal of Continuing Education in Nursing, 45(9), 393-401.

Küçük, S., Kapakin, S., \& Göktaş, Y. (2014). Tıp Fakültesi Öğrencilerinin mobil cihazları kullanım durumları ve mobil öğrenmeye yönelik görüşleri. VIII. Ulusal T1p Eğitimi Kongresi, 7-9 Mayıs, İstanbul.

LITFL- Life in the fast line. (2014). FOAM: Free Open Access Meducation. 21.10.2016 tarihinde http://lifeinthefastlane.com/foam/ adresinden erişilmiştir.

MacDermid, J.C., Solomon, P., Law, M., Russell, D., \& Stratford, P. (2006). Defining the effect and mediators of two knowledge translation strategies designed to alter knowledge, intent and clinical utilization of rehabilitation outcome measures: a study protocol. Implementation Science, 1(14), 1-11.

Maldonado, R. (2011). The use of multimedia clinical case scenario software in a problem-based learning course: impact on faculty workload and student learning outcomes. The Journal of Physician Assistant Education, 22(3), 51-55.

May, N. (2016). Generation Why - Challenges in Medical Education at \#NSWMET. 21.10.2016 tarihinde http://stemlynsblog.org/generationwhy/ adresinden erişilmiştir.

MOTE (2010). Türk Tabipler Birliği mezuniyet öncesi tıp eğitimi raporu. 27.02.2016 tarihinde http://www.ttb.org.tr/kutuphane/mote_2010.pdf adresinden erişilmiştir.

Musal, B., Keskin, O., \& Tuncel, P. (2016). Dokuz Eylül Üniversitesi Tıp fakültesi mezuniyet öncesi tıp eğitiminde e-PDÖ uygulaması: İki yıllık deneyim. Türkiye Klinikleri, Tıp Ĕ̈itimi Özel Sayısı, 1(3), 17-24. 
Musal, B., Akalın E., Kılıç, O., Esen, A. \& Alıcı, E. (2002). Dokuz Eylül Üniversitesi Tıp fakültesi probleme dayalı öğretim programı, süreçleri ve eğitim yönlendiricilerinin rolü. Tıp Eğitimi Dünyası, 9, 39-49.

Nickson, C.P., \& Cadogan, M.D. (2014). Free open access medical education (FOAM) for the emergency physician. Emergency Medicine Australasia, 26, 7683.

Onan, A. 2011. Probleme dayalı ăgsal öğrenmenin tıp fakültesi öğrencilerinin transfer becerileri ve özyeterlilik algllarına etkisi (Yayımlanmamış yüksek lisans tezi). Ankara Üniversitesi, Eğitim Bilimleri Enstitüsü, Bilgisayar ve Öğretim Teknolojileri Eğitimi ABD, Ankara.

Persson, A.C., Fyrenius, A., \& Bergdahl, B. (2010). Perspectives on using multimedia scenarios in a PBL medical curriculum. Medical Teacher, 32(9), 766-772.

Rounds, L., \& Rapport, B. A. (2008). The successful use of problem-based learning in an online nurse practitioner course. Nursing Education Perspectives, 29(1), 12-16.

Savin-Baden, M. (2006). The challenge of using problem based learning online. In Savin-Baden, M. \& Wilkie, K. (Eds.), Problem-based Learning Online (pp. 313). Maidenhead: McGraw Hill.

Schmidt, H. G., Rotgans, J. I., \& Yew, E. H. (2011). The process of problem-based learning: what works and why. Medical Education, 45(8), 792-806.

Sezer, B., Odabaşı, O., \& Abay, Ş. E. (2014). Tıp Fakültesi öğrencilerinin eöğrenmeye yönelik tutumları ve örnek bir uzaktan eğitim uygulamasına ilişkin görüşleri (Hacettepe Üniversitesi Örneği), VIII. Ulusal Tıp Eğitimi Kongresi, 79 Mayis, İstanbul.

Spinello, E. F., \& Fischbach, R. (2008). Using a Web-Based Simulation as a Problem-Based Learning Experience: Perceived and Actual Performance of Undergraduate Public Health Students. Public Health Reports, 123(Suppl 2), 78-84.

Strobel, J., \& van Barneveld, A. (2009). When is PBL More Effective? A Metasynthesis of meta-analyses comparing PBL to conventional classrooms. Interdisciplinary Journal of Problem-Based Learning, 3(1), 44-58.

Şendağ, S., \& Odabaşı, F. (2009). Effects of an online problem based learning course on content knowledge acquisition and critical thinking skills. Computers and Education, 53, 132-141.

TEDMEM. (2016). OECD Yetişkin becerileri araştırması: Türkiye ile ilgili sonuçlar. Ankara: Türk Eğitim Derneği Yayınları.

Turan, S. \& Demirel, Ö. (2011). Hacettepe Üniversitesi tıp fakültesi öğrencilerinin probleme dayalı öğrenmeye yönelik tutumları ve görüşleri. Eğitim ve Bilim, 36(162), 16-30.

UTEAK (2014). Mezuniyet öncesi tıp eğitimi ulusal standartları. 21.10.2016 tarihinde http://www.uteak.org.tr/uploads/belge/MOTE_STANDARTLAR_2014.pdf adresinden erişilmiştir. 
Valaitis, R. K., Sword, W.A., Jones, B., \& Hodges, A. (2005). Problem-based learning online: Perceptions of health science students. Advances in Health Sciences Education, 10, 231-252.

Vasiliou, C., Ioannou, A., Arh, T., Zaphiris P., \& Klobučar, T. (2013). Technologyenhanced problem based learning. $32^{\text {nd }}$ International Conference on Organizational Science Development, 20-22 March, Portorož, Slovenia.

Vosinakis, S., Koutsabasis, P., Zaharias, P., \& Belk, M. (2012). Problem-based learning in virtual worlds: Two case studies in user interface design. In Mark, C. \& Withnail, G. (Eds.), Experiential learning in virtual worlds - Exploring the complexities (pp.1-21). Inter-Disciplinary Press.

Yıldırım, A. \& Şimşek, H. (2005). Sosyal bilimlerde nitel araştırma yöntemleri. Ankara: Seçkin Yayıncılık.

Yıldız-İnanıc1, S. (2014). Öğrenci gözüyle probleme dayalı öğrenme oturumlarının değerlendirilmesi: Stres Modülü. VIII. Ulusal Tıp Eğitimi Kongresi, 7-9 Mayıs, İstanbul.

Zubaidah, S. (2005). Problem-based learning: Literature review. Singapore Nursing Journal, 32(4), 50-55. 